INTERNATIONAL

FOOD POLICY

RESEARCH

INSTITUTE

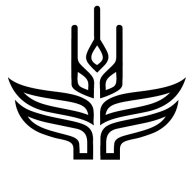

CGIAR Institutions, and Markets

Led by IFPRI

December 2019

\title{
Reforming Agricultural Support for Improved \\ Environmental Outcomes
}

\author{
Abdullah Mamun \\ Will Martin \\ Simla Tokgoz
}

Markets, Trade, and Institutions Division 


\section{INTERNATIONAL FOOD POLICY RESEARCH INSTITUTE}

The International Food Policy Research Institute (IFPRI), established in 1975, provides research-based policy solutions to sustainably reduce poverty and end hunger and malnutrition. IFPRI's strategic research aims to foster a climate-resilient and sustainable food supply; promote healthy diets and nutrition for all; build inclusive and efficient markets, trade systems, and food industries; transform agricultural and rural economies; and strengthen institutions and governance. Gender is integrated in all the Institute's work. Partnerships, communications, capacity strengthening, and data and knowledge management are essential components to translate IFPRI's research from action to impact. The Institute's regional and country programs play a critical role in responding to demand for food policy research and in delivering holistic support for country-led development. IFPRI collaborates with partners around the world.

\section{AUTHORS}

Abdullah Mamun (a.mamun@cgiar.org) is a Research Analyst in the Markets, Trade, and Institutions Division of the International Food Policy Research Institute (IFPRI), Washington D.C.

Will Martin (w.martin@cgiar.org) is a Senior Research Fellow in the Markets, Trade, and Institutions Division of IFPRI, Washington D.C.

Simla Tokgoz (s.tokgoz@cgiar.org) is a Research Fellow in the Markets, Trade, and Institutions Division of IFPRI, Washington D.C.

\footnotetext{
Notices

${ }^{1}$ IFPRI Discussion Papers contain preliminary material and research results and are circulated in order to stimulate discussion and critical comment. They have not been subject to a formal external review via IFPRI's Publications Review Committee. Any opinions stated herein are those of the author(s) and are not necessarily representative of or endorsed by IFPRI.

${ }^{2}$ The boundaries and names shown and the designations used on the map(s) herein do not imply official endorsement or acceptance by the International Food Policy Research Institute (IFPRI) or its partners and contributors.

${ }^{3}$ Copyright remains with the authors. The authors are free to proceed, without further IFPRI permission, to publish this paper, or any revised version of it, in outlets such as journals, books, and other publications.
} 


\title{
Reforming Agricultural Support for Improved Environmental Outcomes*
}

\author{
by \\ Abdullah Mamun, Will Martin and Simla Tokgoz \\ International Food Policy Research Institute
}

13 December 2019

Agricultural support has changed substantially in both rich and poor countries in recent years. In rich countries, there has been a strong move to decoupled subsidies and a fall in average rates of protection. In developing countries, market price support remains the dominant form of protection and average rates of support have risen - breaking the traditional pattern of taxing agriculture. Emissions from agriculture and land use change have contributed up to a third of total greenhouse gas emissions, with beef, milk and rice production accounting for more than 80 percent of agricultural emissions. Agricultural support was biased against emission-intensive goods until recent years and is now only slightly biased towards them. Although emission intensities are relatively higher in the developing countries, they have fallen far more rapidly in developing countries than in the rich countries in the past quarter-century, as agricultural productivity has grown in developing countries. Policy reform will be challenging given the strong politicaleconomy support for the current structure of protection. Increasing investments in research and development to raise productivity and lower the emissions intensity of agricultural output would help agriculture and the environment.

JEL Codes: F18, F64, Q18, H23, Q58

Keywords: agriculture, agricultural support, environment, greenhouse gases, market price support.

* We wish to thank Lars Brink, Shenggen Fan, Joe Glauber, Thom Jayne, David Laborde, Rob Vos and participants in seminars at IFPRI and the Meridian Institute for valuable comments. We alone are responsible for all remaining errors. This work was undertaken as part of the CGIAR Research Program on Policies, Institutions, and Markets (PIM) led by the International Food Policy Research Institute (IFPRI). Funding support for this study was provided by the Food and Land Use Coalition and PIM. This paper has not gone through IFPRI's standard peer review procedure. The opinions expressed here belong to the authors, and do not necessarily reflect those of PIM, IFPRI, or CGIAR. 


\section{Executive Summary}

\section{Does agricultural support contribute to environmental degradation?}

Agricultural production and land use change leave a significant environmental footprint. They are responsible for roughly a quarter of global greenhouse gas (GHG) emissions. Support measures promoting agricultural production with existing technologies therefore likely contribute to environmental degradation and climate change. However, assessing the impact is not straightforward, as environmental outcomes depend on how agricultural policies influence the mix of goods produced and how those goods are produced. The present study addresses two key questions in this context: (i) what are the implications of existing support measures for agricultural output and emissions? and (ii) how might these support measures be repurposed to help improve environmental, social, and nutritional outcomes?

\section{Governments provide nearly US\$600 billion in agricultural support every year}

Globally, agricultural support is very substantial, with farmers in 51 key countries receiving US $\$ 483$ billion per year between 2015 and 2017, enough to raise their returns by 18 percent on average. The same set of countries spent US\$86 billion per year on public goods that create enabling conditions for agriculture, such as agricultural innovation systems and rural infrastructure; and $\$ 50$ billion per year in transfers from taxpayers to consumers. Given the extremely high returns estimated for these public goods, governments could well over-invest in farm-level support and under-invest in providing public goods that could both contribute to food security and to agriculture's contribution to climate change mitigation and adaptation.

\section{Some forms of support distort agricultural markets more than others}

Agricultural support can be divided into three types: (i) trade or border measures such as tariffs or quotas that provide market price support (MPS); (ii) coupled subsidies (CS) provided by governments as direct subsidies on output or as subsidies on inputs (such as fertilizers or seeds) that create incentives to increase output; and (iii) decoupled subsidies (DS) that avoid altering incentives to change output levels but provide direct income support to farmers.

In the trade context, there is a clear ranking of these measures, with market price support being the most distorting, because it simultaneously increases supply and reduces demand relative 
to the quantities consistent with market prices in the absence of support measures. Coupled subsidies to producers are generally less distorting because they affect only supply, while decoupled subsidies are least distorting because, at least in principle, they are meant to affect neither supply nor demand. This ranking is much less clear when the focus is on the impact on GHG emissions. For instance, market price support through trade policies creates a stronger incentive to reduce output in trade-competing countries, than would be the case for coupled subsidies.

\section{The nature of agricultural support has changed substantially}

The traditional pattern of agricultural support involved substantial support to farmers in the rich countries, while poor countries, on balance, used to tax agriculture. This pattern has changed substantially over the past decades (see Figure A).

Figure A. Nominal rates of assistance by type of support

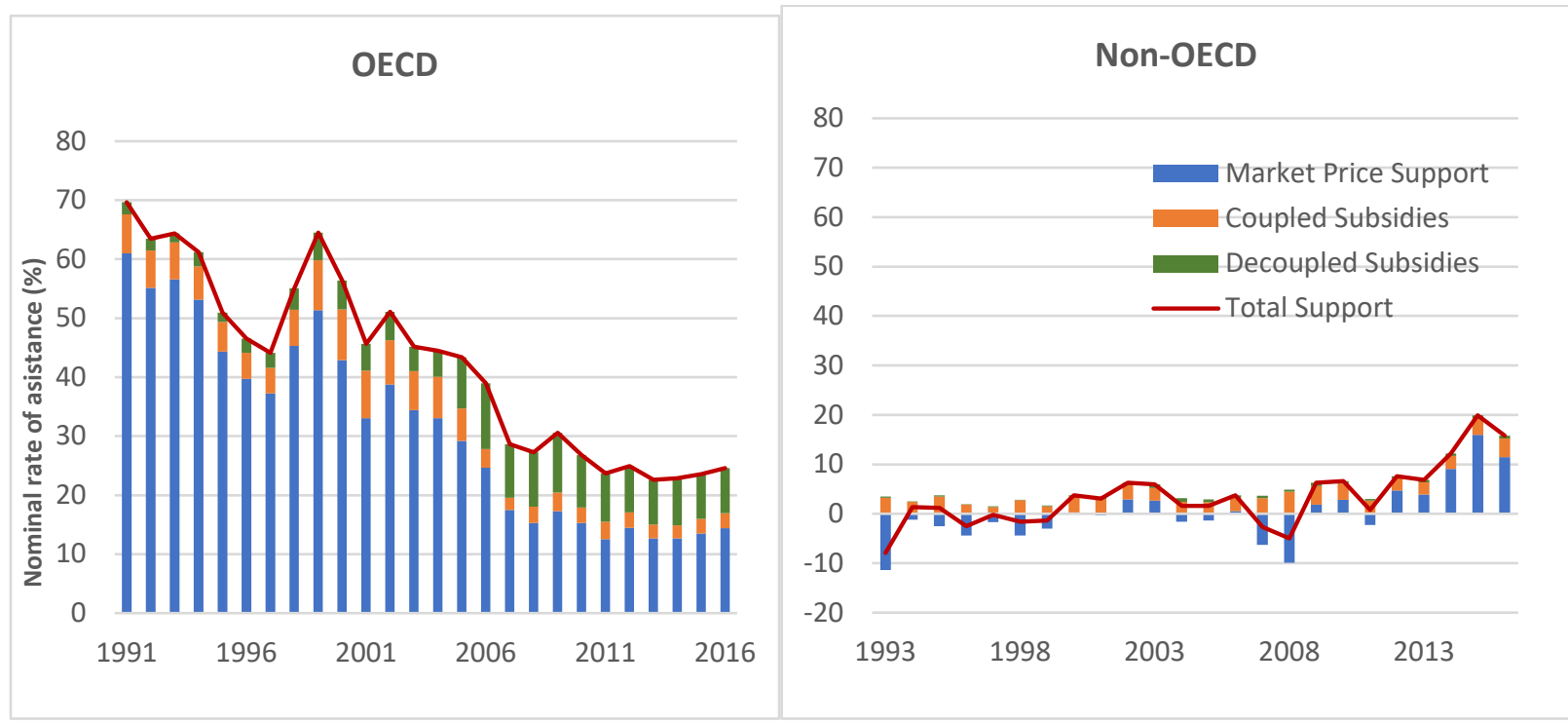

Note: Support is expressed as a \% of value of production at undistorted prices (i.e., prices net of the country's own tariffs and subsidies).

In wealthy nations, average rates have fallen and there has been a move away from trade measures and towards decoupled subsidies to avoid costly increases in agricultural production and reductions in consumption, and to enhance the agricultural trade opportunities of partner countries. In developing countries, by contrast, agricultural support has shifted from net taxation to net assistance on average. Nowadays, most developing country support is provided through border measures that generate revenues, such as tariffs, rather than subsidies paid by 
governments. Since market price support rarely requires budgetary funding, it usually does not face the same scrutiny as output or input subsidies. Overall, most support to world agriculture is provided through market price support, rather than subsidies.

\section{GHG emissions from agriculture are strongly concentrated by product}

How does the present regime of agricultural support impact on the environment and on GHG emissions, in particular? Clearly, this depends on the extent to which support induces greater production and the emission intensity (emission per unit of output) of the kind of production being supported. To assess the overall impact on emissions, it is important to note that at present GHG emissions are strongly concentrated by product. Ruminant meat, milk and rice production account for more than 80 percent of agricultural emissions, with ruminant meat alone accounting for half of these in both OECD and developing countries. Milk and ruminant meats are roughly twice as emission-intensive in poorer countries than in today's OECD countries-a difference that is strongly related to differences in productivity. At the same time, however, agricultural emission intensities (emissions per unit of output) have been falling much more rapidly in nonOECD countries than in OECD countries. This is fortunate, particularly given that agricultural production has been growing much more rapidly in the developing world (2.6 percent per year vs 0.5 percent per year in developed countries). As a result, the share of developing countries in global emissions from agricultural production has remained close to that reached in 1991 (74 percent).

Land use and land use change also contribute substantially to global emissions. Deforestation is the most important of the related emissions and much of which - in turn -is driven by expansion of production of emission-intensive commodities, especially livestock products. While forests in the OECD countries and in most of Asia reduce atmospheric $\mathrm{CO}_{2}$ by converting it through photosynthesis, there are substantial net emissions from deforestation in South America, South East Asia, and Africa.

\section{Agricultural policies are more-or-less neutral in supporting high emission-intensive vis-à-vis low emission-intensive products}

Agricultural support provides an incentive for expansion of global agricultural output by increasing its profitability, although the actual impact is likely quite small as increases in overall 
output require producers either to draw new land into agriculture or find ways to raise land productivity (e.g., by increasing fertilizer use or using improved cultivars). Hence, as a first, simple approach one can assess the likely impact of agricultural support by identifying whether the support is biased towards emission-intensive products or not. As shown in this paper, in the early 1990s, this bias appears generally to have been away from emission-intensive goods. By 2015, however, with the shifts in policies, average support was neither biased towards more nor towards less emission-intensive commodities.

\section{How to realign agricultural support?}

Given the importance of emissions from agriculture and land use change, measures to mitigate them are almost certainly needed if effective reductions in global emissions are to be achieved. This is particularly the case given that demand for the most emission-intensive goods — red meat and dairy products - is likely to increase more rapidly than demand for staple foods because of income growth in developing countries and increase in rate of urbanization.

Policy reform will be challenging given the strong political support for the current system. Experience suggests that focusing on a narrow reform agenda is particularly difficult because the interested parties in such a discussion are those who would lose from abolition of this support. To increase the chances of success, reformers need to make a careful strategic decision about the breadth of the policy agenda, including measures that would generate benefits to key interest groups. The Uruguay Round of trade negotiations is an important example of an extremely broad agenda that succeeded - by bringing in additional interest groups, such as those focused on trade in services - in introducing massive reforms in agricultural incentives. However, there is an optimal span of topics for reform advocacy and/or negotiation because greater breadth also increases the complexity of communicating results and potentially the challenges of reaching agreement.

Another key question relates to the geographic focus of reform efforts. The global nature of the GHG problem suggests a global effort is needed, but most of the policies that influence global outcomes are determined at national or sub-national levels, where governance mechanisms are much more strongly developed. Reaching effective agreements at the global level has proved difficult, but such agreements have the advantage of allowing governments to make lasting commitments for reform. 


\section{Support should shift from the farm to public goods}

Given the vast support currently being provided to farmers, there are clearly many potential approaches that might be used to achieve better economic, environmental and nutritional outcomes. From the available evidence it seems likely that such reform packages would include investments in $R \& D$ to raise productivity; investments in $R \& D$ that reduce emission intensities; and incentives to reduce consumption of red meats and dairy products in (high-income) countries with already excessive intake (by nutritional standards) of such products. Increases in productivity may or may not reduce emission intensities but have a potentially important impact on land-use emissions by reducing the long-run agricultural land-use footprint, and, particularly, the adverse impacts of deforestation.

However, successful policy reform is not brought about simply by identifying such policy packages. Successful reform advocacy tends to combine analysis focused on identifying policy challenges and reforms, and coalition building focused on achieving reforms. A key question is which interest groups might engage in reform of agricultural subsidies in the future. Reformers need to develop a reform narrative that frames the issues in a way that makes the benefits of reform clear and mobilizes a range of actors in support of a specific approach to reform. Discourse coalitions can help build such a shared understanding and identify narratives that will convey its essence to broader groups of stakeholders. While the road to such reform is likely to be long and hard there is, at last, a great deal of attention focused on how this might be done. 


\section{Introduction}

The fifty-one developed and developing countries covered by the OECD's 2018 agricultural policy monitoring and evaluation provided $\$ 483$ billion per year in 2015-17 in support to farmers (OECD 2018, p105); \$86 billion on services such as agricultural innovation, infrastructure and stockholding; and $\$ 50$ billion in transfers from taxpayers to consumers. Most of the $\$ 483$ billion in support to farmers is provided in the form of trade measures that raise (or lower) prices received by farmers relative to world prices, with $\$ 69$ billion of this provided in the form of direct subsidies. While agriculture has many environmental impacts, we focus on emissions of greenhouse gases (GHG) because of their global impact and their potentially catastrophic consequences for the world, and for agriculture in particular. With agricultural production and land use change contributing close to a quarter of global GHG emissions, this spending has potentially large implications for greenhouse gas emissions and hence for climate change. However, the magnitude and even the direction of these policy impacts is uncertain, making analysis essential for well-founded policy recommendations.

These incentives affect environmental outcomes by changing (i) how much is produced, (ii) what is produced, (iii) where it is produced, and (iv) how goods are produced. To assess the environmental impact of agricultural subsidies, we need to account for the output-related effects ((i), (ii) and (iii)) and the technology effects (iv). Support that is coupled with output of emission-intensive goods generally increases output in the region providing support and the associated emissions. Use of coupled subsidies will be particularly damaging for global emissions if the emission intensity (emissions per unit of output) is higher in the region providing support than in other regions, or if it encourages the use of emission-intensive practices or technologies. Similarly, subsidies coupled with specific inputs will encourage greater use of those inputs and may generate increased emissions, particularly if the input is emission-intensive. Decoupled subsidies, by contrast, are expected to transfer revenues directly to recipients without altering market incentives, potentially reducing economic and environmental costs and providing greater net benefits to producers per dollar of support because they do not require costly increases in output.

Support to farmers may also have favorable impacts on environmental outcomes. If, for instance, support is provided primarily for products that are relatively less emission-intensive, it 
may take resources away from emission-intensive activities. If support is provided subject to conditions designed to improve environmental outcomes it may also help to reduce emissions. Support may also be designed to create incentives for producers to use climate-smart production approaches that both reduce costs and contribute to better environmental outcomes (Engel and Muller 2015) or to help the agricultural sector to adapt to climate change (Glauber 2018).

Reform should not focus solely on achieving the "right" set of agricultural support measures. Policy makers are pursuing multiple goals when promoting agricultural development - including achieving food security, improving incomes for farmers, and rectifying market failures such as environmental externalities and the lack of incentive for individual farmers to invest in research and development that results in under-investment in agricultural R\&D. To achieve multiple targets, a basic rule of thumb states that policy makers must have at least as many policy instruments as they have goals (Tinbergen 1956). Fortunately, policy makers have many policy instruments including different types of agricultural subsidies and measures affecting emissions and nutritional outcomes more directly. Widely-used measures with important impacts on agriculture include: (i) provision of public goods such as rural infrastructure, agricultural research and development, and water rights, (ii) consumer taxes or subsidies that influence the demand for agricultural products without being directly identified as producer subsidies or taxes, (iii) policies affecting demand and supply in downstream value chains of agricultural commodities (e.g., biofuel policies ${ }^{1}$ ). Considering the full range of relevant policies is important not just for achieving the goals of any individual policy maker, but also for helping reach agreement on policy reforms, especially where different stakeholders have sharply different interests and/or preferences.

Many critiques of current agricultural support — and agricultural policies more generally-have pointed to contradictions at the heart of current policies. Most support is provided in the form of higher prices or direct subsidies that create deadweight economic losses, provide most of their benefits to larger producers, and are capitalized into land values (Goodwin et al. 2012), while policymakers frequently under-invest in public goods such as research, innovation and infrastructure. Support varies widely by commodity and is frequently lavished on

\footnotetext{
${ }^{1}$ Which may be provided indirectly through mandates or regulations on fuel use or through exemptions from duties otherwise levied on fuel use and are not considered in the OECD measures of agricultural support.
} 
foods that are particularly large sources of greenhouse gases. Towering subsidies in rich countries deny poor farmers in developing countries the opportunity to compete. Many people remain unable to access enough food because they are too poor to be able to buy food. At the same time, the diets of many others include excessive quantities of fat, meat and sugar, which have contributed to an epidemic of non-communicable diseases such as diabetes (Masters et al. 2015). Many critiques of current policies and of outcomes such as consumption of beef and sugar above nutritionally-desired levels in the industrial countries are available (e.g., Tilman and Clark 2014; Springmann et al. 2017; Willet et al. 2019), but few studies offer plans for concrete action to improve the situation.

In the next section of the paper, we consider the range of policy instruments used to influence agricultural outcomes and the extent to which they change farmers' incentives to produce. In the third section we focus on the greenhouse gas emissions associated with agriculture and land use change. Then, in the fourth section, we consider the potential impacts of subsidies and related measures on emissions. The fifth section examines policy conditionality and targeting. With this as backdrop, the sixth section considers potential paths to reform, given political-economy constraints on reform. Conclusions are presented in section VII.

\section{Agricultural Support and Related Measures}

Support to and taxation of agriculture comes in many forms, but it is useful to distinguish three main forms of support: ${ }^{2}$ (i) market price support, (ii) coupled subsidies, and (iii) decoupled subsidies. Governments generate market price support by introducing barriers to trade such as tariffs, licenses and quotas that raise (or lower) the domestic price relative to world prices. Coupled subsidies include measures such as subsidies to output or to inputs that increase the returns to producers and hence their incentives to produce specific goods. Decoupled subsidies base payments on something fixed, such as production in an historical period and remove the

\footnotetext{
${ }^{2}$ Throughout this study, we build on the OECD measures of agricultural incentives. Market Price Support is defined as in the OECD PSE Manual (OECD 2016). Coupled subsidies refers to the budgetary transfers and revenue foregone due to measures specific to agriculture, administered in ways that create incentives to change output levels. Decoupled subsidies are measures intended to avoid creating incentives to change output, specifically categories E (production not required); F (Payments based on non-commodity criteria) and G (miscellaneous payments) of the OECD (2016, p23)
} 
link between support and output levels. In addition to the support provided in the form of subsidies, governments also intervene to improve the enabling environment for agriculture, providing goods that would otherwise be under-provided, such as research and development and rural infrastructure. Governments also intervene in many ways that indirectly affect agriculture, but outside the scope of support as conventionally defined, such as by imposing mandates for use of biofuels and improving access of poor people to food through social safety net programs.

These forms of support differ in two important ways - whether governments need to fund them directly, and how they influence production. Market price support is generally found in importing countries, where the fact that tariffs raise revenue makes it attractive to policy makers and reduces the need for (frequently rigorous) review by Ministries of Finance. Subsidies, by contrast, need to be funded from scarce government resources and so tend to undergo regular scrutiny. Market price support distorts both consumption and production decisions, while coupled subsidies directly distort only production.

Historically, developed countries have tended to support agriculture, frequently using trade barriers to limit imports. Developing countries have also imposed export taxes aiming to lower domestic prices and, hence, lowering food costs to consumers, while reducing returns to producers. Some developing countries have also taxed the agricultural sector to generate government revenue, especially by taxing exports of cash crops during commodity-price booms. Developed countries, in contrast, put more emphasis on coupled subsidies in addition to market price support. A number of developing countries also use coupled subsidies, sometimes to offset the adverse impacts of export taxes on farmer incentives. As shown by Anderson (1995), there were strong political-economy reasons for poor countries to tax agriculture and for rich countries to support it. Historically, few countries have provided decoupled subsidies, even though those provide more direct income support to producers and hence are easier to target.

Figure 1 presents the average nominal rate of protection (NRP) for agriculture for highincome and developing countries, underlining the above discussion. The NRP reflects the support provided by border measures such as tariffs and quotas, or taxation imposed through measures such as export taxes or quotas. NRPs in high-income countries rose until the late 1980s and have since declined. NRPs in developing countries were negative until the early 1990s but have since become modestly positive on average. 
As protection to agriculture in the industrial countries rose in the 1970s and 1980s (Figure 1), it created increasing conflict between countries, with exporters dismayed by the low prices that ensued when other exporters paid substantial export subsidies - and the subsidizers realizing that their expensive subsidies were depressing world prices rather than achieving their desired goal of raising producer prices (Johnson 1991). Reforming these policies was challenging, and required a sustained push from policy reformers, accompanied by policy analysis identifying options for reform and analyzing their consequences. During the Uruguay Round, WTO members identified approaches that would allow them to begin the process of reducing support provided through border measures (Martin and Winters 1996).

Figure 1. Nominal Rates of Protection in High Income and Developing Countries, \%

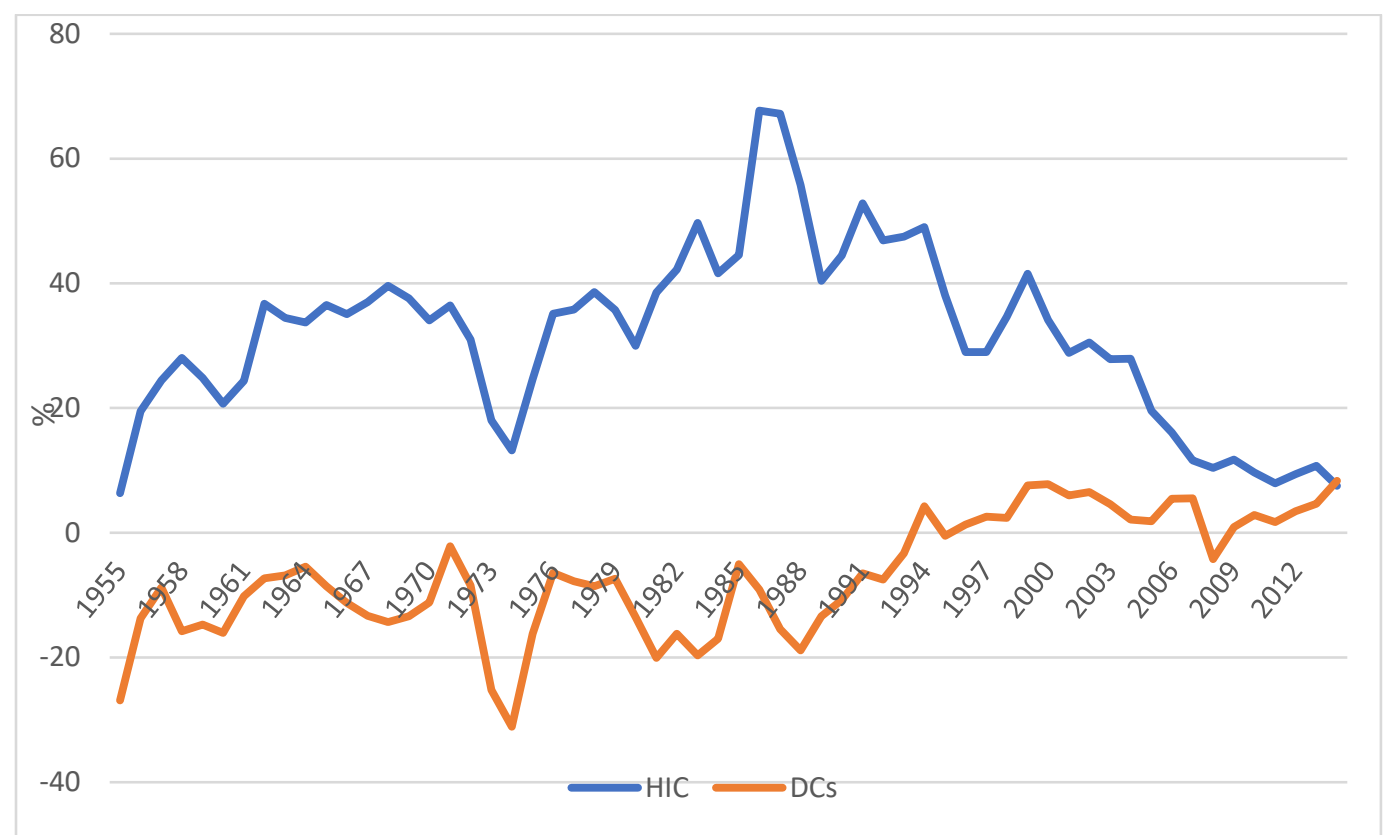

Sources: For period 1955-2004, Anderson (2009); for period 2005-2014, Ag Incentives Consortium, www.agincentives.org.

While the restrictions on industrial country support to agriculture under the Uruguay Round were weaker than they seemed (Hathaway and Ingco 1995), they appear to have had an enormous impact on applied rates of agricultural protection. After rising continuously between the $1950 \mathrm{~s}$ and the late 1980s — except for a sharp decline during the 1973-4 commodity boom-border support in the industrial countries fell sharply from the early 1990s. In the developing countries, 
the limits on agricultural support were much weaker relative to prior levels of support, and the sharp upturn in economic growth rates of developing countries beginning in the early 1990s contributed to an increase in border protection from the consistently negative rates prior to the 1990s to, on average, slightly positive assistance since that time (Martin 2018a).

While there are many ways to disaggregate protection data geographically, we focus primarily on the distinction between the on-average richer OECD countries and non-OECD countries. We do this to investigate the differences in the overall emission intensity and emission levels between these groups of countries. We also consider this split because of the sharp differences in patterns of support between these two groups. Supplementary data for several key countries are given in the appendix.

The WTO limits on market price support are commodity-specific while those on domestic subsidies include flexibility to average across many commodities. Decoupled subsidies are, by design, essentially unconstrained by WTO rules. These rules might be expected to result in a shift in support away from market price support. To see whether this has been the case, we compare the evolution of these three different forms of support in Figure 2. For this analysis, we turn to the OECD database that covers 85 percent $^{3}$ of global agricultural production (12 nonOECD and almost all OECD economies) and allows us to disaggregate protection measures in the way that we need, although its coverage of smaller developing countries is less than in the broader "Ag Incentives" database ${ }^{4}$ underlying Figure 1.

\footnotetext{
${ }^{3}$ Based on value of production at PPP prices from FAOSTAT.

${ }^{4}$ See www.ag-incentives.org
} 
Figure 2. Nominal Rates of Assistance, \%, by type of support

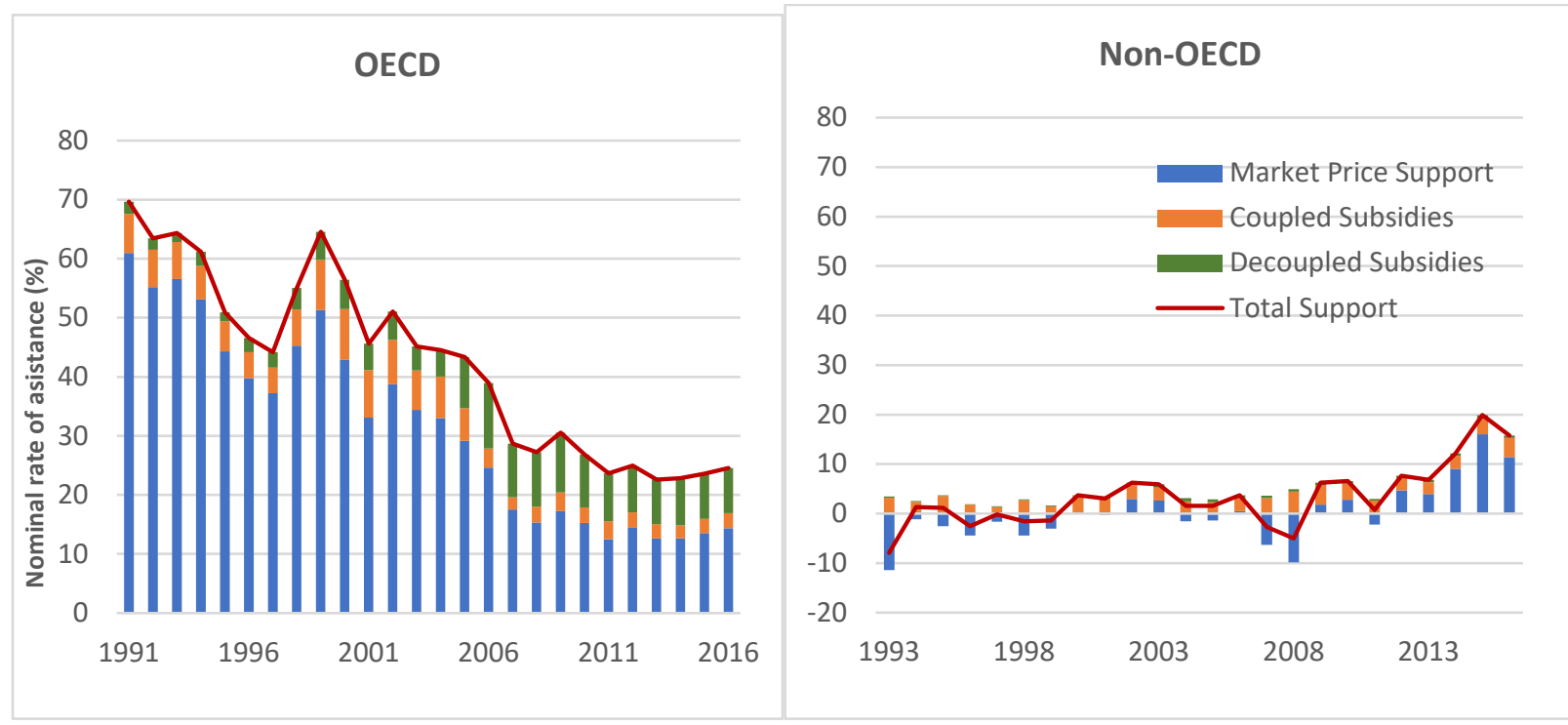

Note: Support is expressed as a \% of value of production at undistorted prices (i.e. prices net of the country's own tariffs and subsidies).

Source: OECD (2018) for all countries for 1991 to 2016, and Anderson (2009) for India 1991 to 1999.

As shown in Figure 2, a key change in OECD country protection since 1990 has been a sharp decline in the rate of assistance provided through market price support, associated with an increase in decoupled subsidies. Market price support in the OECD countries fell from over 60 percent in 1991 to 13 percent in 2016, computed as market price support in share of agricultural sectors' value of production. By contrast, decoupled support rose from only 2 percent in 2006 to a peak of 11 percent in 2006, declining to 8 percent in 2016, as a share of agricultural production value. Distorting coupled subsidies such as output and input subsidies declined from almost 7 percent of agricultural production value in 1991 to 2.6 percent in 2016. However, market price support has risen slightly in recent years, suggesting a continuing tendency for support to rise when world prices fall.

In non-OECD countries, total support was much more volatile, being negative in the early 1990s and around the 2007-2008 price spike and oscillating around zero in most years up to 2013. However, between 2014 and 2016, it increased dramatically, peaking at 19.9 percent of the value of production at undistorted prices in 2015. Most of the support in non-OECD countries is in the market price support category and decoupled subsidies remain very small. Coupled subsidies, such as those on output and on inputs such as fertilizer and water, accounted for about a quarter of total support in 2016 
To understand developments in OECD countries' support to agriculture, it's important to look at the two largest players, the European Union (EU28) and the United States, as shown in Figure 3. In the European Union, support was almost exclusively provided by market price support in 1990, with only 2.7 percentage points of the 87.6 percent nominal rate of assistance consisting of decoupled payments. From the early 2000s, however, decoupled subsidies began to replace coupled subsidies, with both market price support and coupled subsidies dropping dramatically as a share of the value of output, while decoupled subsidies rose sharply in importance. By 2016, decoupled subsidies accounted for 15 percent out of 25 percent in total support. In the United States, both the share and the level of market price support fell sharply over the period. Both coupled and decoupled subsidies rose dramatically during the period of depressed world prices beginning in 1998. By 2016, total support, at 9 percent, was less than half the level in 1991 and decoupled support made up close to half of that support.

Figure 3. Nominal Rates of Assistance in the EU28 and the USA by type of support (in \%)

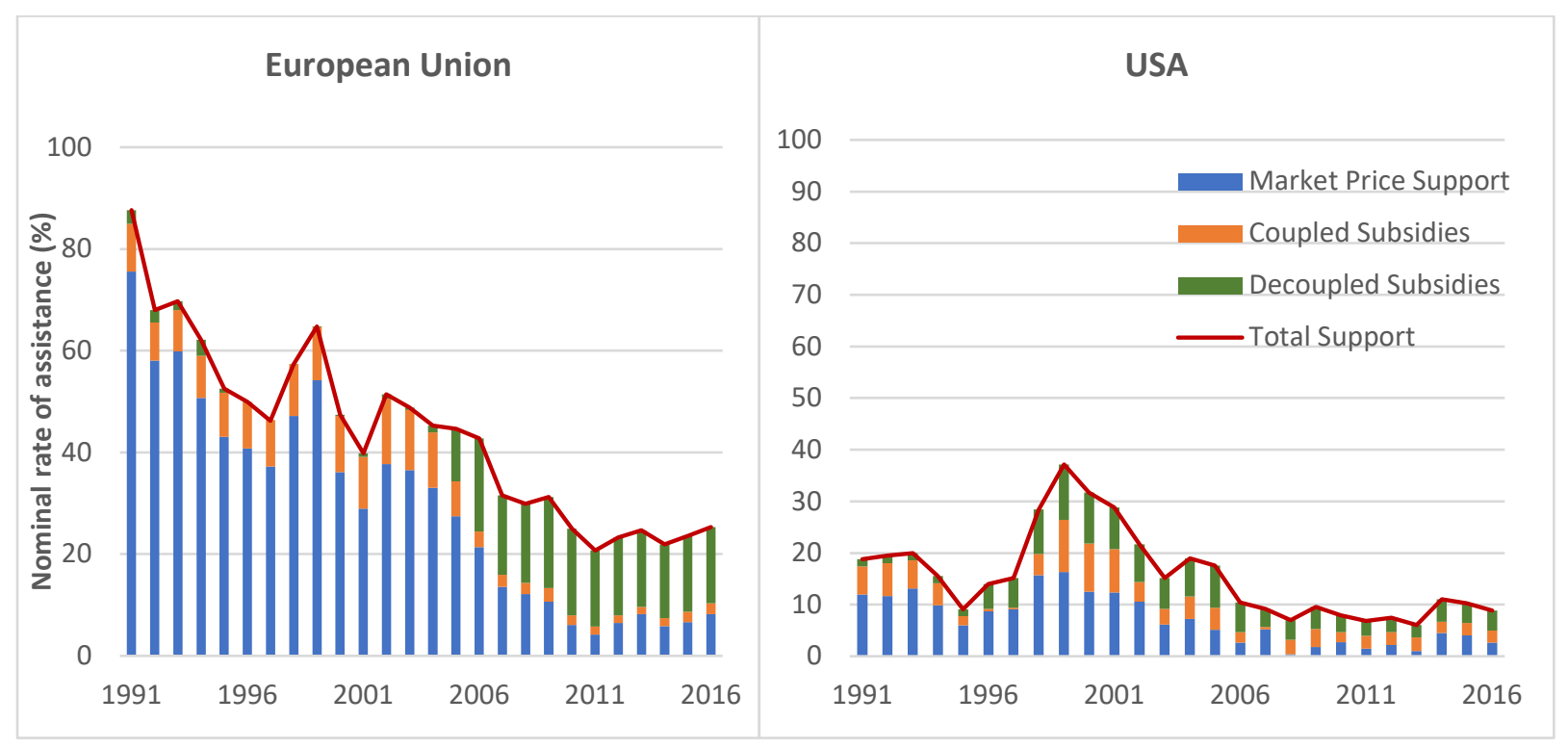

Note: All measures as defined in Figure 2.

Given the size of China and India as agricultural producers, changes in average agricultural support to non-OECD countries tend to be driven by changes in their support. In China, the picture is very clear, with nominal rates of assistance trending up from about 2000 from the negative levels that had prevailed in the 1980s and 1990s. While China provided some coupled 
subsidies and decoupled subsidies, these were very small throughout the period relative to market price support. Roughly half of the market price support was provided to maize, pork, rice and wheat in 2015 (OECD 2018). Since then, market price support to maize has fallen dramatically with the abolition of the administered price for maize (WTO 2019).

In India, market price support has been negative and substantial throughout most of the period, although the rate of taxation on agriculture declined sharply in the last two years of the sample. Because domestic prices are insulated from world market prices, the market price support/taxation for individual commodities varies sharply from year to year, but the commodities with the largest negative transfers - accounting for more than half the total negative MPS — on average between 2005 and 2016 were milk, rice, wheat, bananas and mangoes. Coupled subsidies, mostly in the form of input subsidies, have been positive throughout the period but substantially below the rate of agricultural taxation leaving total assistance strongly negative in most years.

Figure 4. Nominal Rates of Assistance in China and India by Type of Support (in \%)

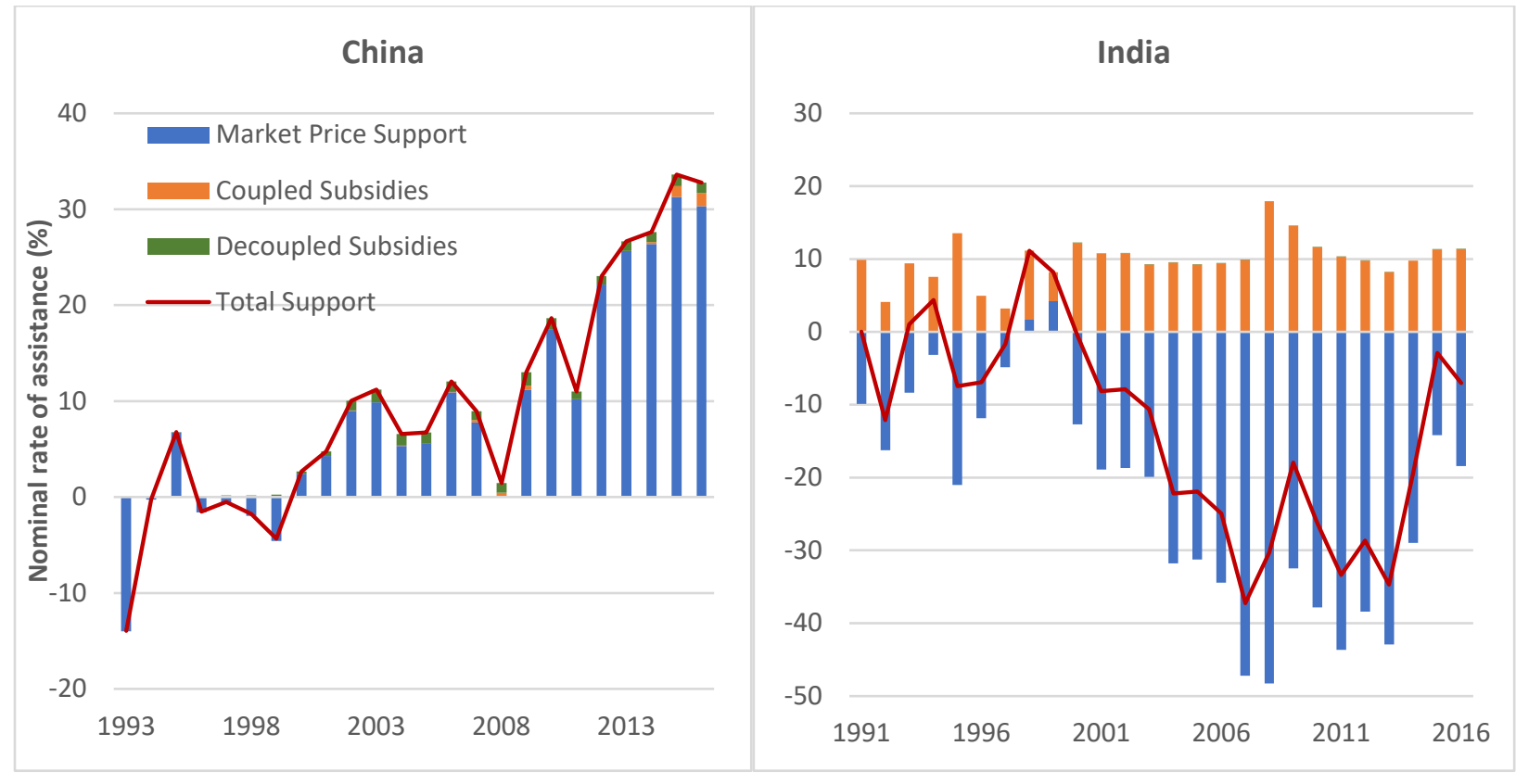

Source: OECD (2018) for China for 1993 to 2016, OECD (2018) for India for 2000 to 2016, and Anderson (2009) for India 1991 to 1999. 
The impact of agricultural support on environmental externalities is influenced both by the extent to which they increase agricultural output and the extent to which they change the mix of products produced. Since the responsiveness of overall food demand and supply to prices is low, output is not likely to be greatly changed by agricultural support. However, switching land between agricultural commodities is relatively easy so the relative incentives to produce different types of food are likely to be important.

If support is substantial and linked to output of emission-intensive commodities such as rice and livestock products, then support will increase emissions from these products. The average support rate to individual commodities is shown in Figure 5 for both OECD and nonOECD emerging economies. This measure includes only measures that support individual commodities, either through market price support or output/input subsidies and therefore almost entirely excludes decoupled transfers. Within the OECD, the highest rate of assistance is provided to the production of rice, followed by that of sugar and livestock products. For the nonOECD countries, rice, wheat, sugar and milk all have relatively high rates of support. Within both groups of countries, there is considerable variation across commodities 
Figure 5. Transfers to specific commodities, 2014-16 (in \% ad valorem equivalent)

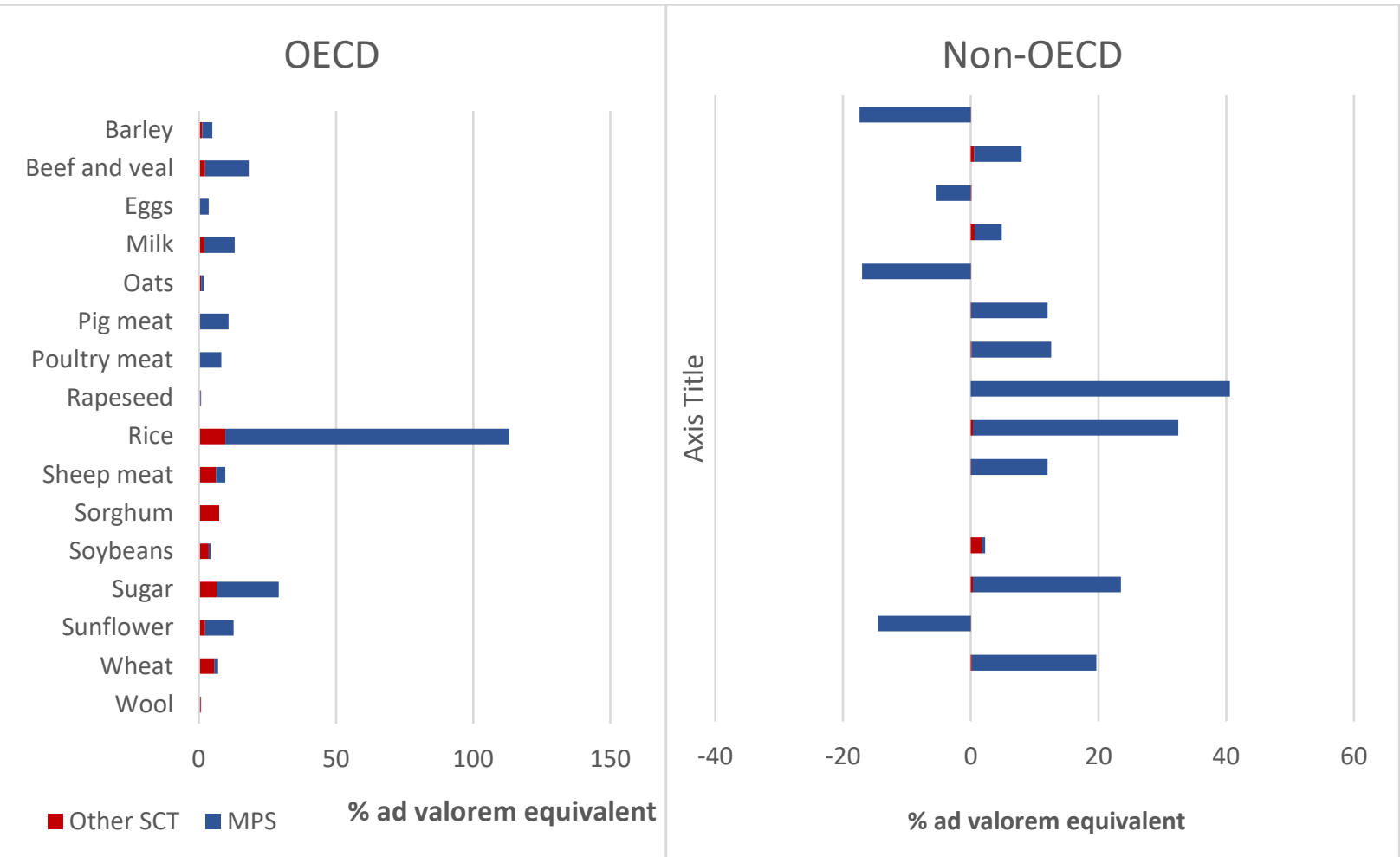

Note: Other SCT refers to Single Commodity Transfers other than those provided by Market Price Support. All percentages are relative to the "undistorted" value of production.

Source: OECD (2018) for all countries for 1991 to 2016, and Anderson (2009) for India 1991 to 1999.

Both OECD and non-OECD countries provide public goods such as agricultural research and innovation investments and rural infrastructure. The benefit-cost ratios for these interventions have been found to be generally substantially greater than one (Mogues et al. 2012; Alston 2018; Fan, Cho and Rue 2018), with the highest rates of return to investments in research and development. By contrast the benefit-cost ratio for subsidies is almost by definition less than one because of the deadweight costs associated with inducing high-cost production and distorting consumer choices (through changing domestic prices). In both country groups, public-good investments are small relative to total support. In the OECD countries, they average around 12 percent of total support (OECD 2018), with the largest allocations going to infrastructure and research and knowledge generation. In the non-OECD countries, this type of support averaged around 16 percent of total support, with the largest amount spent on public stockholding and most of the remainder on infrastructure and knowledge generation. 
One important study in this context is Henderson and Lankoski (2019) that analyzed the relationship between agricultural support policies (using OECD PSE database) and a set of environmental impacts. This analysis was conducted in a range of country settings, using a farmlevel and a market-level model. Based on the methods and environmental indicators used, market price support and payments based on unconstrained variable input use were the most environmentally harmful among the various PSE measures. Decoupled subsidies based on noncurrent crop area were the least harmful. The impacts of support policies that clearly change the competitiveness of one production activity in relation to another, such as payments based on current crop area or on current animal numbers, were more equivocal.

\section{Emissions from Agriculture and Land Use}

When considering mitigation priorities, a key question is the importance of each emission source, simply because any given percentage reduction in emissions has a larger impact, the larger the underlying flow of emissions. Figure 6 compares emissions from agriculture and landuse change with those from non-agricultural sources such as energy and industry, transport and residential/commercial uses. This figure makes clear that agriculture and land-use change are major sources of global GHG emissions. With almost a quarter of global net emissions, they clearly need to be addressed if comprehensive reductions in emissions are to be achieved. Another striking feature of the graph is the small contribution made to emissions from international transport, including bunkers for shipping and aviation fuel, relative to other sources of emissions. 
Figure 6. Global GHG Emissions by Source, 2010 (shares in \%)

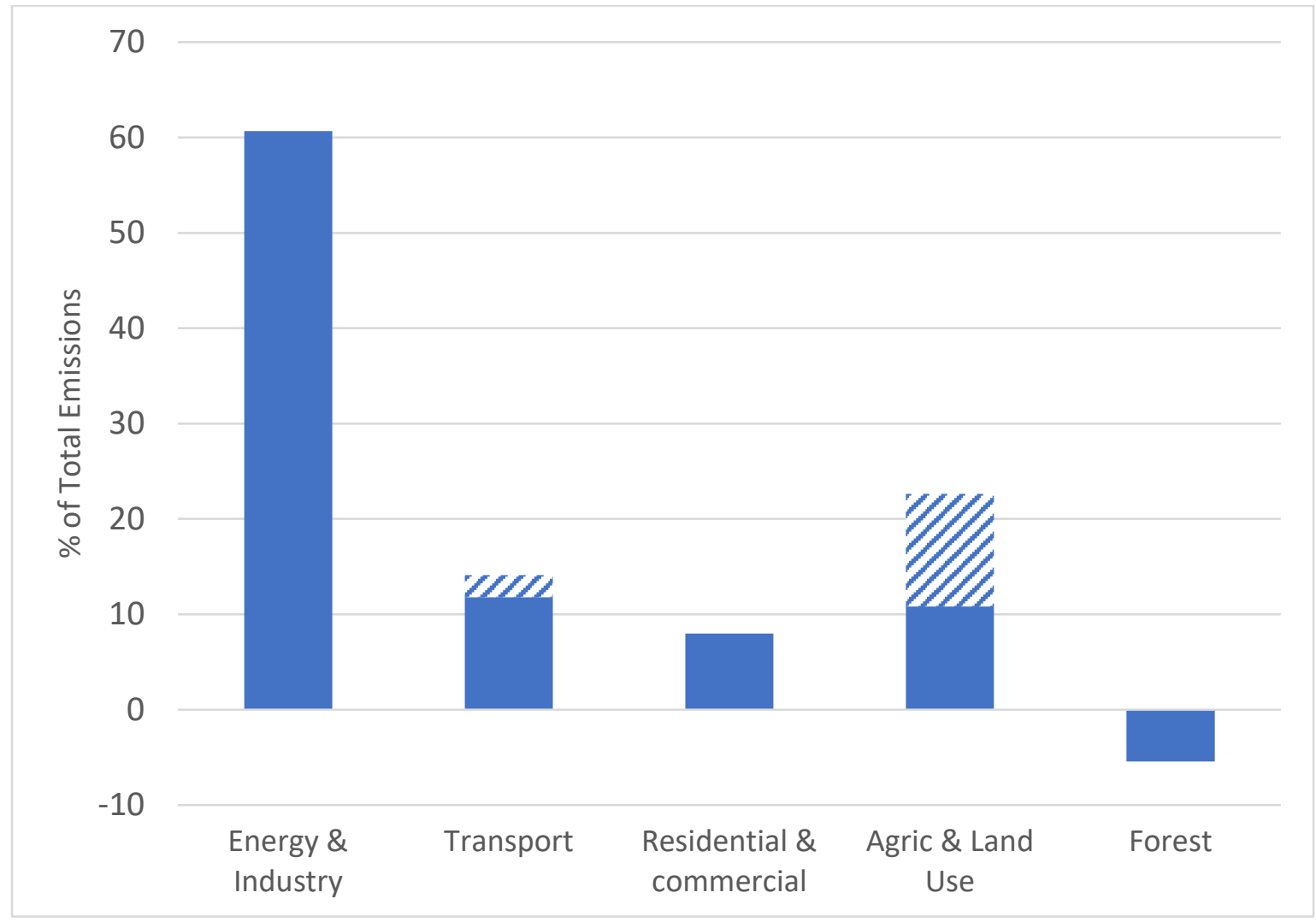

Source: FAOSTAT. Note: The striped section of the Transport bar refers to international transport, while the striped section of the Agric \& Land Use bar refers to land use, excluding carbon sequestration by forests, which is shown in the last bar.

In the next sub-section of this paper, we focus on the existing flow of emissions from agriculture, while in the following one we consider emissions from land use and land-use change.

\section{Emissions from Agricultural Production}

Since most distortions to agricultural incentives are commodity-specific, emissions per unit of commodity output are needed to understand the direct impact of agricultural distortions on emissions. Fortunately, Tubiello et al. (2012 and 2013) developed such a set of measures and estimates based on this methodology are freely downloadable from FAOSTAT (Tubiello 2019). These estimates are based on the IPCC Tier 1 Methodology that uses relatively stylized estimates of emissions per unit of output by region (IPCC 2006), these estimates are still sophisticated 
enough to differentiate between regions based on key agro-ecological features ${ }^{5}$. While the original database, as documented in Tubiello et al. (2013), included only rice and livestock products, the current version also includes non-rice cereals. Tubiello et al. (2013) note that these GHG emission estimates cover over 80-85 percent of total agricultural sector emissions, of which the majority comes from livestock (Tubiello et al. 2012). Estimates of agricultural emissions by commodity as a share of total emissions for included sectors are presented in Table 1 .

Table 1. Agricultural Emissions ${ }^{1}$ by Commodity and Country Grouping, 2015 (shares in \%)

$\begin{array}{lccc} & \text { OECD } & \text { Non-OECD } & \text { World } \\ & \% & \% & \% \\ \text { Rice } & 3.4 & 18.8 & 15.5 \\ \text { Other Cereals } & 18.7 & 7.4 & 9.8 \\ \text { Milk } & 18.8 & 17.8 & 18.0 \\ \text { Ruminant meat } & 49.2 & 50.5 & 50.2 \\ \text { Pigmeat } & 7.3 & 3.2 & 4.0 \\ \text { Poultry meat } & 1.4 & 1.3 & 1.3 \\ \text { Eggs } & 1.1 & 1.1 & 1.1 \\ \text { Total (from included sectors) } & 100 & 100 & 100 \\ \text { Note: } 1 \text {. Measured in } \mathrm{CO}_{2} \text { equivalent. } & & & \end{array}$

Source: FAOSTAT, Accessed 2 February 2019

A striking feature of Table 1 is the large share of ruminant meat (cattle, buffalo, goats and sheep) in total emissions, both in the OECD and in the rest of the world. Another striking feature is the enormous difference in the importance of rice between the OECD and the non-OECD countries. Milk production emissions accounts for around 18 percent in both regions. Pigmeat and poultry products account for only six percent of total emissions globally, and less than 10 percent even in the OECD countries. Close to 70 percent of emissions are associated with production of ruminant meat and milk largely because emissions resulting from enteric fermentation in the ruminant digestive process and emissions associated with manure are important contributors to global emissions from agriculture (see Tubiello et al. 2013, p6). The shares of emissions from the

\footnotetext{
${ }^{5}$ See IPCC (2006, Ch 10) for details of the attributes used to distinguish between livestock production systems in different countries and Tubiello $(2013, \mathrm{p} 5)$ for very specific references to the emissions factors used by product and region. In this section, the listing of non-OECD countries is comprehensive.
} 
non-OECD group are much closer to the world average shares because non-OECD emissions from agriculture are 3.6 times as large as those from the OECD group.

The substantial support to milk production in both OECD and non-OECD countries is seen in Figure 5. This and the even more significant support to beef production in the OECD countries clearly have important implications for producer incentives. The fact that most of this support is provided through market price support is something of a mixed blessing. Market price support is clearly worse than coupled subsidies when the focus is on trade impacts since market price support in protecting countries increases production in these countries and lowers global prices. However, when the focus is on global emissions, the feature that is adverse for trade (i.e., the larger reduction in prices outside the group of protecting countries) has a favorable impact. Countries not providing protection through market price support —or providing less than the average amount of support-face lower external market prices and reduced incentives for production than if the same amount of producer support were provided by coupled subsidies in the protecting country. This distinction is fundamental and does not appear to have been considered in other studies. In fact, it reverses the widely used ranking of MPS and coupled subsidies under which MPS is considered more perverse than coupled subsidies (Mayrand et al. 2003, p41). While capturing the quantitative effect of this distinction requires a formal model, it is important to recognize it in a broad study of this type.

To the extent that market price support in OECD countries stimulates output in those countries while depressing output in other countries, it is important to examine differences in the emission intensity of production in each region. Table 2 reveals some striking differences in emission intensities between commodities, with emissions per $\mathrm{kg}$ of output twice as high for ruminant meat and more than twice as high for milk in non-OECD countries relative to the OECD. By contrast, emissions per unit of output were substantially lower in the non-OECD countries for rice and for pigmeat. 
Table 2. Average Emission Intensities by Commodity and Country Grouping (kg of $\mathrm{CO}_{2} \mathrm{eq}$ per kg of output).

$\begin{array}{lccc} & \text { OECD } & \text { Non-OECD } & \text { World } \\ \text { Rice } & 1.1 & 0.9 & 0.9 \\ \text { Other Cereals } & 0.2 & 0.2 & 0.2 \\ \text { Milk } & 0.5 & 1.3 & 1.0 \\ \text { Ruminant meat } & 16.0 & 32.4 & 26.6 \\ \text { Pigmeat } & 1.7 & 1.4 & 1.5 \\ \text { Poultry meat } & 0.3 & 0.7 & 0.6 \\ \text { Eggs } & 0.5 & 0.8 & 0.7\end{array}$

Source: Authors' calculation based on FAOSTAT data on emissions and output.

Another important question about emissions is where they are generated. Are they primarily generated in the rich countries, with diets heavy in livestock products? Or in developing countries, which accounted for nearly 90 percent of the value of agricultural production in 2015. As shown in Table 3, it turns out that this dietary composition effect is outweighed by the much greater production volumes in developing countries, and the higher emission intensities discussed above. The OECD share of emissions is highest for pigmeat and cereals other than rice and, at the other extreme, less than 5 percent for rice.

Table 3. Distribution of Emissions by Region (shares in \%)

$\begin{array}{lccc} & \text { OECD } & \text { Non-OECD } & \text { Total } \\ \text { Rice } & 4.8 & 95.2 & 100 \\ \text { Other Cereals } & 41.4 & 58.6 & 100 \\ \text { Milk } & 22.9 & 77.1 & 100 \\ \text { Ruminant meat } & 21.4 & 78.6 & 100 \\ \text { Pigmeat } & 39.1 & 60.9 & 100 \\ \text { Poultry meat } & 23.3 & 76.7 & 100 \\ \text { Eggs } & 22.2 & 77.8 & 100 \\ \text { Total } & 21.8 & 78.2 & 100\end{array}$

The sharp differences in emission intensities between OECD and non-OECD countries raise an important question about the future path of emissions. What would happen to total emissions from developing countries if, with rising per capita incomes, they followed the path of the industrial countries by changing consumption and production patterns towards higher shares of 
milk and ruminant meats, without changing their emission intensities? One simple way to assess this is to calculate the total emissions that would arise from producing the current OECD output mix with the current non-OECD emission intensities. This indicates that emissions would be 78 percent higher than current OECD emissions. This is a troubling result, given the likely path of global food demand and supply with consumption of animal products increasing sharply as global food demand becomes more driven by per capita income growth than by population growth, as was the case in the past (Fukase and Martin 2017). It should be noted that the trade patterns, i.e., import of dairy and meat products by developing countries with high emission intensities for these products from developed countries with low emission intensities for these products, would complicate the answer to this question.

One important thing to keep in mind, however, is that the greenhouse gas emission intensities of production tend to decline strongly in response to agricultural productivity growth (Gerber et al. 2011). Since agricultural productivity growth is an important driver of overall economic growth and poverty reduction and appears to have been more rapid in developing than developed countries in recent years (Martin 2018a), productivity growth may be an important offsetting factor to an otherwise inexorable increase in agricultural emissions. Because the emissions coefficients in the FAOSTAT emissions database reflect the impact of productivity growth on emissions intensities, it is possible to examine the changes in emission intensity of production in OECD and non-OECD countries since the early 1990s.

Table 4. Annual Reductions in Emission Intensity by product, 1991-2015 (growth rates in \%)

$\begin{array}{lccc} & \text { OECD } & \text { Non-OECD } & \text { World } \\ \text { Rice } & -0.5 & -0.8 & -0.8 \\ \text { Other Cereals } & -0.4 & -0.6 & -0.5 \\ \text { Milk } & -1.7 & -1.3 & -1.1 \\ \text { Ruminant meat } & -0.5 & -1.1 & -0.6 \\ \text { Pigmeat } & -1.0 & -2.0 & -1.6 \\ \text { Poultry meat } & -1.0 & -1.9 & -1.2 \\ \text { Eggs } & -0.4 & -0.7 & -0.4\end{array}$

Source: Authors' calculations based on FAOSTAT emissions data.

Table 4 presents estimates of the annual reductions in the emissions intensity of production between 1991 and 2015. Emission intensities are declining across the board for all 
countries. Furthermore, for all products, except milk, these declines in emission intensities are more rapid in non-OECD countries than in OECD countries. While the annual reductions in emissions may look relatively small, over time, their cumulative effect are bound to be substantial.

The results presented in Table 4 highlight a potentially important role of investments in research and development in reducing emissions from agriculture. Past reductions in emission intensities reflect primarily producers' attempts — aided by innovations developed by public and private research expenditures - to lower their production costs and raise their incomes. The reduction in emission intensities would accelerate if additional investments in R\&D were focused on reducing costs, increasing productivity, and reducing emission intensities. If, for instance, additional R\&D were to focus on the problem of emissions due to enteric fermentation, which accounted for 44 percent of total agricultural emissions in 2010 (Tubiello et al. 2012), then it seems likely that more rapid progress might be made in dealing with this challenge. Boadi et al. (2004) point to a range of potential approaches for reducing these emissions. Given the inherent inefficiency of methane emissions from digestive processes, it seems likely that many approaches to dealing with this problem would be climate-smart by reducing input and resource use as well as emissions per unit of output.

\section{Emissions from Land Use Change}

Emissions from land use are heavily influenced by changes in stocks of carbon, rather than ongoing flows such as those emanating from enteric fermentation or other emissions associated with agricultural production. This dependence on stock changes is most clear in the case of deforestation, where sequestered carbon is converted rapidly into $\mathrm{CO}_{2}$ as trees are burned in the land-clearing process. Carbon sequestration as forests grow also involves a stock adjustment process, with carbon dioxide being converted into sugars by photosynthesis and then into wood and other carbon sinks, as well as soil carbon sequestration where $\mathrm{CO}_{2}$ in the atmosphere is stored in soil.

Key numbers on emissions from land use and land use change are presented in Table 5. These numbers show emissions from forest land, cropland, grassland and burning of biomass. For forests, the data can be divided into the sequestration of carbon resulting from forest growth and the release of carbon through deforestation resulting from conversion of forests into 
cropland. The numbers show the overwhelming importance of deforestation in determining net emissions from land use and land use change. In the OECD countries, where net deforestation is small or negative, the absorption of carbon into carbon sinks created by forest growth exceeds the emission of $\mathrm{CO}_{2}$ equivalents due to deforestation and generates negative net emissions. For non-OECD countries, the emissions due to deforestation exceed the absorption of $\mathrm{CO}_{2}$ from forest growth. The next most important influence on emissions from land use change is burning of biomass. This highlights the importance of moving away from cultivation practices that involve burning crop residues, towards approaches such as zero-till, that allow for incorporation of residues into the soil, creating a potentially important sink for $\mathrm{CO}_{2}$.

Table 5. Emissions from Land Use and Land-Use Change, 2015

$\begin{array}{lrrr} & \text { OECD } & \text { Non-OECD } & \text { World } \\ \text { Forest land } & -834 & 1875 & 1040 \\ \quad \text { Forest } & -959 & -884 & -1843 \\ \quad \text { Conversion } & 125 & 2759 & 2883 \\ \text { Cropland } & 116 & 551 & 667 \\ \text { Grassland } & 13 & 33 & 46 \\ \text { Burning Biomass } & 254 & 1651 & 1905 \\ \text { Total } & -451 & 4110 & 3659 \\ \text { Source: FAOSTAT. Note: Values are in millions of tonnes of } \mathrm{CO}_{2} \text { equivalent. }\end{array}$

Land use and land-use change patterns not only differ starkly between OECD and non-OECD countries, but also by geographic region, as can be seen in Table 6. In North America, Europe and Oceania, forests form a net $\mathrm{CO}_{2}$ sink. In Europe, $\mathrm{CO}_{2}$ withdrawals by forests more than offset emissions from all other land use and land-use changes. In contrast, forest conversion is a significant source of GHG emissions in Africa, South America, and Southeast Asia. Emissions from burning biomass are particularly large in Africa and Southeast Asia. 
Table 6. Emissions from Land Use and Land Use Change by region, 2015

$\begin{array}{lrrrrrrr} & \text { Africa } & \text { Asia } & \text { Europe } & \begin{array}{c}\text { North } \\ \text { America }\end{array} & \text { Oceania } & \begin{array}{c}\text { South } \\ \text { America }\end{array} & \begin{array}{c}\text { Southeast } \\ \text { Asia }\end{array} \\ \text { Forest land } & 805 & 646 & -808 & -186 & -90 & 685 & 859 \\ \quad \text { Forest } & -227 & 53 & -871 & -246 & -94 & -393 & 331 \\ \quad \text { Conversion } & 1032 & 592 & 63 & 60 & 4 & 1079 & 529 \\ \text { Cropland } & 53 & 394 & 125 & 53 & 32 & 9 & 356 \\ \text { Grassland } & 12 & 17 & 5 & 7 & 2 & 3 & 14 \\ \text { Burning Biomass } & 728 & 661 & 84 & 246 & 82 & 96 & 647 \\ \text { Total } & 1599 & 1718 & -594 & 120 & 25 & 793 & 1877 \\ \text { Source: FAOSTAT. Note: Values are in millions of tonnes of } \mathrm{CO}_{2} \text { equivalent. } & & & \end{array}$

As noted by Byerlee (2019), deforestation in developing countries was, until the late 20th century, largely for domestic production of staple foods. However, rapid income growth in developing countries has contributed to growth in demand for livestock products which, in turn, has sharply increased demand for livestock feed inputs, such as soybeans. Deforestation in tropical areas is also associated with expanding land use for export production of palm oil and soybeans. Some of this production is for biofuels, and policy makers have begun to express concerns about the potential impact of these policies for deforestation. As emphasized by Byerlee (2019), dealing with the deforestation problem is likely to require a multi-strand approach, including sustainable intensification to reduce the footprint of agriculture, improvements in land tenure to reduce the incentives for deforestation created by market failures.

\section{Implications of Agricultural Support for Emissions}

Agricultural production receiving support should be expected to increase relative to the output of other commodities. Since agriculture's share of GHG emissions is much larger than its share of global GDP, one may also expect this to lead to an increase in global emissions. However, this effect is generally thought to become more muted over time as the scope for further land expansion is limited by arable land constraints and by far most of future production increase would have to come from increased resource efficiency (FAO 2017). Further, higher production coming from land expansion would decrease prices and mitigate the impact partially. Nonetheless, given continued deforestation this may not be a given. 
Changing the output mix of agriculture could be another future pathway, as long as consumers are also willing to substitute from more to less resource-intensive agri-food commodities. Clearly, the relative magnitude of these output and transformation effects is an important question for future modeling work, but some progress can be made by looking at the broad structure of incentives.

A key question that arises, given the concentration of GHG emission in the set of agricultural activities highlighted in Tables 1 to 3, is whether the current structure of agricultural support is GHG-unfriendly in terms of encouraging output of these emission-intensive commodities relative to other agricultural products. A preliminary indication on this question can be obtained by comparing the rate of support for these commodities relative to other agricultural commodities. We calculate this relative incentive to produce as $\left(\frac{1+s_{e i}}{1+s_{o}}\right)$ where $s_{e i}$ is the proportional support rate on emission-intensive agricultural commodities (ruminant meat, milk, rice, other cereals, pigmeat, poultry meat and eggs), and $s_{o}$ is the support rate on other agricultural commodities. This ratio is presented in Figure 7 for the OECD, non-OECD and the world during the 1993 to 2016 period over which agricultural support information is available for the largest countries.

Figure 7 shows that, in the early 1990s, the direct impact of global agricultural incentives slightly favoring lower emission-intensive agricultural commodities, as reflected in the relative incentive ratio of 0.85 in 1993 . This finding is perhaps surprising given the vertiginous rates of protection on some high emission-intensive commodities in some industrial countries during the 1980s and 1990s. In 1987, for example, the nominal rate of protection for milk in the EU was an astounding 350 percent. ${ }^{6}$ The relative support ratio for the OECD countries varied over the period but ended up close to its original level of 0.9. By contrast, support in non-OECD countries appears to have changed in a way that - on average - encourages output of emission-intensive goods relative to other commodities, as the relative incentive ratio increased from 0.85 to 1.05 . These numbers for the direct impacts could overestimate the full impact on global emissions, however, because most of the related support was provided through trade policies, which raise consumer prices and, hence, likely have reduced demand for those goods in countries with trade

\footnotetext{
${ }^{6}$ Based on data from the OECD PSE database extracted 2 March 2019.
} 
barriers, while they reduced output in countries without such protection and facing depressed world prices. $^{7}$

Figure 7. Relative incentives for emission-intensive and other agricultural goods.

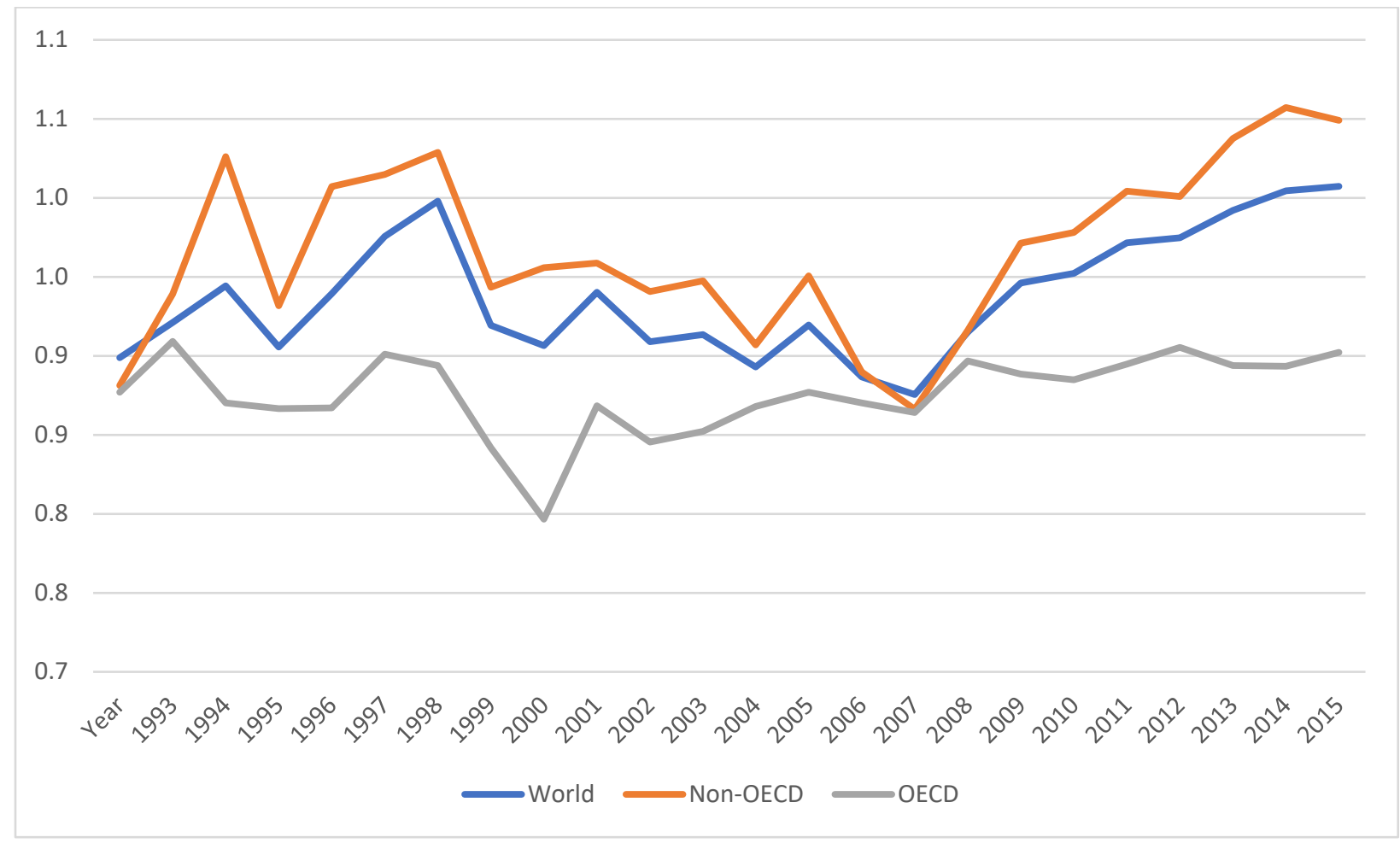

Source: Authors' calculations based on FAOSTAT and OECD (2018)

The slight rise in the ratio of support to emission-intensive commodities for the world on average and for non-OECD countries is a concern, but the relatively small differential in support rates seems unlikely to be a major stimulus to output of more emission-intensive commodities. At the same time, there would seem to be a strong case for analysts and policy makers to draw attention to the existence of egregious rates of support to individual emission-intensive commodities and the adverse impacts that such support has both for the trade opportunities of other countries and for the environment.

\footnotetext{
${ }^{7}$ These protection rates for emission-intensive commodities may understate the impact on emissions if support rates are systematically higher on the most emission-intensive goods.
} 


\section{Policy Conditionality and Targeting}

Thus far, our discussion of agricultural support has focused on support that affects incentives to change the level of different agricultural activities, without any direct incentive to change the production technology and particularly without any incentive to reduce emissions per unit of output. But many agricultural support schemes, such as the reformed EU Common Agricultural Policy (Gocht et al. 2017) and the US Farm Program (Lichtenberg 2018), have involved conditionalities designed to achieve better environmental outcomes. Engel and Muller (2015) point to a wide range of approaches that might be used to improve environmental outcomes from agriculture.

There are two broad approaches to policy conditionality in farm programs: (i) paying farmers to refrain from doing something, such as ploughing fragile lands (e.g., the Conservation Reserve Program in the U.S.), and (ii) paying farmers to use farming approaches that are thought to be less environmentally damaging than their previous practices (such as the Environmental Quality Incentive Program in the U.S.) (see Engel and Muller 2015). Frequently, the payment to refrain is implicit, with compliance to a certain minimum standard being required as a condition of eligibility for receiving another benefit, such as a price support.

Two key problems with these approaches are slippage and non-additionality. Slippage arises because participants are likely to use their discretion to minimize both the cost to them and the effectiveness of the action by, for instance, "withdrawing" land of low productivity. Nonadditionality is a problem because it is difficult to avoid rewarding participants for actions they would have undertaken in any event. There is also an indirect land-use change problem. Withdrawing land from agriculture in the US may—by raising world prices — encourage conversion of land from forest to agriculture in other countries, contributing to sizeable emissions from land-use change globally. Partly because of these problems, the impacts of these conditionalities on environmental outcomes have generally been estimated to have quite modest (Gocht et al. 2017; Lichtenberg 2018).

In an era of growing demand pressure (through income and population growth) and climate change, the necessity of protecting natural resources makes the policy environment even more critical. Many countries recognize that conservation of land and water resources is 
necessary to protect their long-term agricultural production potential. Tokgoz et al. (2014) summarize agricultural support allocated to environmental goals for three countries with large agricultural sectors. In 2011, the U.S. allocated \$5 billion for these programs, while Brazil allocated \$ 1.1 billion, and China allocated \$12.4 billion. Most policies that have environmental goals are part of the Green Box ${ }^{8}$ in WTO notifications, as are investments in R\&D and other public-good interventions supporting agriculture, and so none of these measures is restrained by WTO limits on subsidies.

One tempting approach to managing these problems is to move to climate-smart agriculture, involving production methods that are not only more environmentally friendly than current technologies but also reduce production costs and, other things equal, increase the incomes of farmers. However, as noted by Engel and Muller (2015) approaches with these dual advantages are likely adopted even in the absence of incentives for their adoption. As they also note, however, there may be large numbers of resource-poor farmers unable to adopt if there are sizeable fixed costs of adoption, potentially leaving an important role for governments in this context.

Economists usually offer two broad approaches to managing negative externalities such as those resulting from GHG emissions. The first, originally suggested by Pigou (1932) is to impose a tax on the offending output. The second, due to Coase (1960), is to allocate property rights to the scarce resource, in this case the quantity of $\mathrm{CO}_{2}$-equivalent emissions consistent with keeping average global temperatures from rising by, say, $2^{\circ} \mathrm{C}$. A closely-related alternative to such a Pigovian tax is a tradable quota system such as that used to mitigate $\mathrm{SO}_{2}$ emissions in the United States (Schmalensee et al. 1998). These approaches are designed to allow polluters flexibility in the way in which they achieve the desired reductions in externalities, with a view to reducing the costs of achieving that goal. This is in sharp contrast with the more widely-used command and control approaches, where policy makers seek reductions in pollution by mandating specific methods of production, such as requirements to use flue gas desulfurization (“scrubbers") in coal-fired power plants (Schmalensee et al. 1998).

\footnotetext{
${ }^{8}$ Green Box measures are deemed to be non-trade-distorting and are not constrained by countries' WTO commitments on Domestic Support.
} 
An alternative to using conditionality to achieve environmental objectives would seem to be to target payments towards activities that reduce emissions. One challenge with this approach is that - in this context - the payments are directed towards activities that raise costs of production. This would reduce their attractiveness to producers, particularly relative to decoupled payments, which obviate the need to undertake activities that yield less than their social return inherent with conventional subsidies. One possible solution to this problem would be to target such support to development of new techniques that both reduce costs and improve environmental outcomes. If, for instance, an R\&D program could develop an approach to use the methane currently released through enteric fermentation to produce livestock products, then both environmental and farm-income-support goals could be improved.

\section{Achieving Policy Reform}

Policy reform is a challenging undertaking at the best of times. This is partly due to loss aversion on the part of those losing from reform that leads them to overweight these losses relative to any potential gains and partly due to uncertainty among the potential gainers as to whether the reform will eventually occur. These interlocking challengers for reformers were clearly identified and articulated by Machiavelli (1532, p42): “And it ought to be remembered that there is nothing more difficult to take in hand, more perilous to conduct, or more uncertain in its success, then to take the lead in the introduction of a new order of things. Because the innovator has for enemies all those who have done well under the old conditions, and lukewarm defenders in those who may do well under the new." The challenge for reformers is particularly great with a set of policies so complex and well-defended as agricultural subsidies, where there are many stakeholders, many policy makers, many jurisdictions, many goals and many different policy instruments.

Current agricultural policies can clearly be strongly criticized. Vast amounts of resources are expended on subsidies that encourage excessive production in some countries, while producers continue to be taxed in other countries. Global agriculture contributes substantially to the problem of global warming that threatens in the lifetimes of our children to compromise the world's ability to feed itself. Worse, many of the highest subsidies are used to expand the output of the more emission-intensive commodities, foods which appear to contribute strongly to 
increased prevalence of non-communicable diseases worldwide (Tilman and Clark 2014). Biofuel policies ostensibly introduced to reduce emissions by replacing fossil fuels with renewable fuels in transportation end up raising food prices (Zhang et al. 2013; Serra and Zilberman, 2013; Condon, Klemick, and Wolverton, 2015) and likely increasing global emissions once induced land-use changes are considered (Fargione et al. 2008; Searchinger et al 2008; Laborde and Valin 2012).

The expansion of the biofuels sector has led to an intense food-fuel-fiber debate centering on limitations on land and water availability. Seventy percent of the world's fresh water is used for agriculture, much of it extremely wastefully. Furthermore, additional potentially arable land is limited so there is little opportunity to expand by increasing cropped area. Thus, sustainable yield growth is the essential long-term solution to increasing food production in line with demand. Fortunately, there are many paths to increasing yields, such as use of more inputs, investments in mechanization and irrigation, better land management, agricultural $R \& D$, and increases in cropping intensity (ERS 2011; Poudel et al. 2012; Laborde et al. 2016). While governments lavish money on subsidies whose social return is much less than one dollar per dollar invested, far too little is invested in the above channels, especially research and development where the returns per dollar spent are likely $\$ 10$ or more (Alston 2018). Unfortunately, the greater visibility of "benefits" from subsidies allows policy makers to purchase political support each electoral cycle more easily than through more productive longerterm investments in R\&D and rural infrastructure.

The growing demand pressure and supply constraints on world agriculture are visible in food prices. Figure 8 presents food price indices for various agricultural commodities in real terms (FAOSTAT, 2019), showing that prices have increased especially after the 2007-2008 food price crises, even in real terms. Headey and Fan (2008) provide a detailed assessment of the factors behind the food price increases. 


\section{Figure 8. Food price indices (in real terms)}

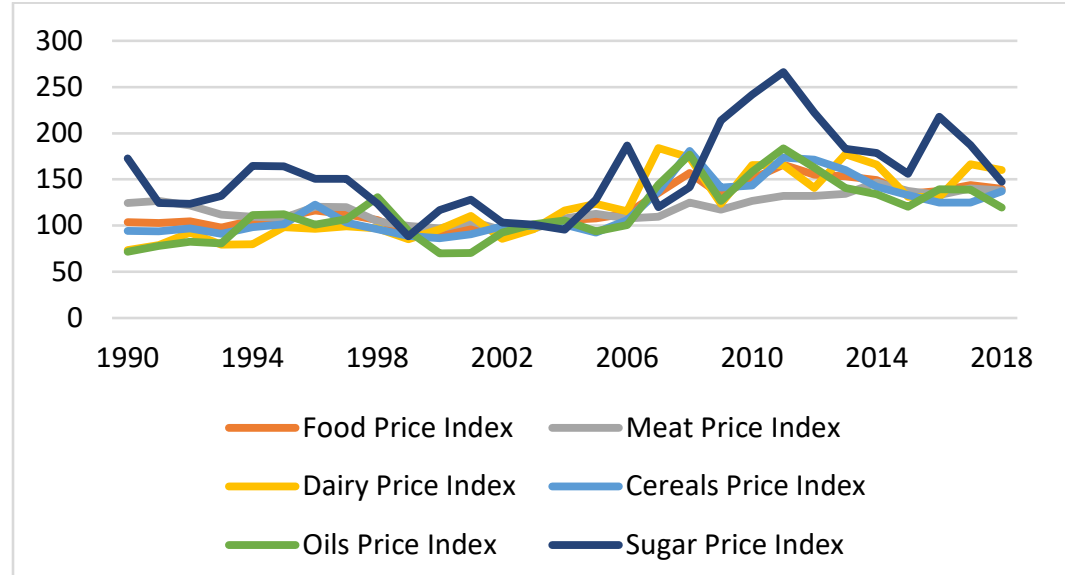

Source: FAOSTAT (2019) Accessed 2 February 2019, Notes: Base year is 2002-2004.

Does the under-investment in agricultural public goods relative to subsidies mean that policy makers are idle or misinformed, not knowing how to resolve these problems and contradictions? Of course not. Agricultural policy makers work hard at balancing the many competing pressures they face and responding to the endless shocks lashing agriculture- - with climate and weather shocks looming large. Even within a country, this is as difficult and dangerous a pursuit as portrayed by Machiavelli. Dealing with problems that require internationally-agreed policies is even more challenging. Key reasons for the disarray that we observe today — as in the past - are the political-economy of the policy process, and the crossjurisdictional nature of many of the challenges (Johnson 1991).

Anderson (1995) uses interest-group models originated by Olson (1971) to provide a compelling explanation for the apparent paradox of high agricultural protection in the rich countries side by side with taxation of agriculture in many developing countries. In poor countries, farmers are numerous and poorly organized. Further, many farmers are focused primarily on subsistence, and not greatly affected by the level of food prices. In the same countries, the urban population is relatively small and, because incomes are low, even urban residents spend a large share of their incomes on food. Because of their proximity, urban residents can organize rapidly, particularly in response to large increases in food prices. This combination of factors tends to lead governments to favor cheap food policies.

As incomes rise, however, these features of the economy change. The farm population declines as urban centers grow. Farmers become more commercial, using more intermediate 
inputs and focusing more on production for the market rather than subsistence. Both these changes increase the leverage of farm prices on farmers' incomes and make them more concerned about the level of farm prices. Urban people become more numerous, making them harder to organize. Further, the increase in their incomes makes urban consumers less concerned about the impact of higher food prices on their real incomes.

This combination of changes first results in reductions in tax rates on agriculture and then increases in protection. When growth is rapid in land-scarce countries, as in China, this change can happen extremely rapidly. Political-economy models have also been shown to explain the evolution of agricultural taxation/subsidization in different countries by changing the costs to policy makers of achieving the redistributions they desire. Low-income net exporters that want lower food prices can achieve this relatively easily by imposing an export tax. Low-income net food importers would need to pay an import subsidy to achieve the same result, but this is rarely done because of the high marginal cost of public funds in poor countries. Similarly, higherincome countries that want to raise food prices to protect their farmers can do so without budget cost if they are net importers. By contrast, net exporters need to pay export subsidies to increase domestic prices and tend to do this more rarely because of its budget costs.

If policies are simply determined by interest-group pressures, with stronger interest groups gaining at the expense of those less well-organized, then there might appear to be no independent role for policy reform. Certainly, the importance of interest groups in policy makes policy reform more challenging. But major reforms have been achieved in some areas that initially looked daunting, such as the Uruguay Round trade agreement involving 123 members (Martin and Winters 1996), while reform has been elusive in more specific areas, such as fertilizer subsidy reform in India (Birner, Gupta and Sharma 2011). A key question is what public policy theory (see, for example, Weible, Sabatier and McQueen 2009) and the lessons of experience (e.g., Martin 1990) can tell us about the possibilities for reforming agricultural policies in the future?

One key step for policy reformers is to frame the debate, by identifying the goals that are important to key stakeholders, and particularly the combination of goals to be addressed in designing a feasible reform package. A second is to identify the policy instruments that might be used to target those goals, and particularly the goals to be considered in developing a reform 
package. A third key design feature is the geographic scope of the reforms. A fourth is the choice of paths to reform. Each of these is addressed in turn in the remainder of this section.

\section{Framing the Debate}

Perhaps the first step in framing debate on policy is to identify how the political system works and who has the power - or potential power - to change policies or to influence those who do (Mayne et al. 2018). With the key audiences identified, framing the debate in the right way is critical for successful reform (Birner, Gupta and Sharma 2011). This involves identifying the goals - not just of the reformers but of all relevant stakeholders - and the combinations of goals to be addressed in the relevant policy reforms.

Key goals relevant for agricultural support policies are:

(i) Food security and nutrition

(ii) Income security, and

(iii) Environmental sustainability.

These three goals may look simple but are, in fact, very subtle, involving many subsidiary goals, such as the Sustainable Development Goals ${ }^{9}$. The challenge of achieving them is greatly increased by the frequency with which many stakeholders identify these goals with outcomes of limited relevance to achieving them, with the most obvious such confusion being that between food security and self-sufficiency. They are also complicated by the need to consider both levels and distribution - both across individuals and over time. While a country may have ample food, the distribution of resources across individuals is what determines whether vulnerable people have access to food, and that access may change sharply over time (Sen 1981).

These goals are strongly related to the more general economic goals of: efficiency, equity, stability and growth. Efficiency is a means to reduce costs and raise real incomes. Most interpretations of the equity goal involve seeking to increase food security and income security. The stability goal includes reducing the exposure of vulnerable people to even short-term food insecurity. Food security has four well-known dimensions, requiring: (i) availability of food, (ii)

\footnotetext{
${ }^{9} \mathrm{https}$ ://sustainabledevelopment.un.org/
} 
access to food, (iii) the ability to utilize food, and (iv) ensuring that volatility does not leave people vulnerable to food insecurity (FAO 1996).

Each of these goals has become considerably more complex in recent years. The nutrition agenda has expanded rapidly in recent years, moving far beyond the traditional identification of malnutrition with consuming insufficient calories (FAO 2013) to encompass concerns about micronutrient deficiencies as well as obesity and its health consequences (Babu, Gajanan and Hallam 2017). This expansion of the nutritional goal has also introduced a link between nutritional outcomes and environmental sustainability emphasized by Springmann et al. (2017), with high consumption of meats with heavy environmental footprints potentially contributing substantially to adverse global environmental outcomes. On environmental sustainability, agriculture is linked with global emissions both as a substantial contributor to emissions and through its vulnerability to climate change.

Furthermore, agricultural subsidies in in many countries, especially in developing countries, are geared towards staple food production such as rice, wheat and maize at the expense of more nutritious foods like vegetables, fruits, beans, eggs, fish. Lower prices for staple foods as the result of these coupled subsidy policies, cause an imbalance of diets of many poor people in both developing and developed countries. Lack of micro-nutrients, or hidden hunger due to poor diets, affect more than 2 billion of people negatively in the world. On the other hand, poor diets also contribute to overweight and obesity of more than 2 million people.

\section{Policy Instruments}

Proponents of reform need to consider a wide range of policy instruments both because at least one instrument is needed for every goal, and because these additional instruments may help to break negotiating logjams. However, the complexity of policy negotiations increases more than proportionately with the number of policy instruments under discussion. A non-exhaustive list of policy instruments affecting, or potentially affecting, agricultural, environmental and nutritional outcomes includes:

(i) Trade policy measures

(ii) Producer subsidies and taxes

(iii) Research, development and extension

(iv) Rural infrastructure 
(v) Greenhouse gas emission taxes or quotas

(vi) Environmental regulations

(vii) Consumer education, food choice "nudges", and taxes

(viii) Biofuel policies

Note that this list includes both the subsidy measures presented in the earlier discussion (in items (i) and (ii)), and a range of other instruments that can be used to affect agricultural, environmental and nutritional targets. Reformers need to be aware of the full range of policy instruments that might be used to target their goals, and to choose judiciously from that set of instruments when deciding how to advance policy reforms. Introducing new instruments may help to achieve goals at lower cost, although it can also complicate the policy debate by adding complexity. An important example of a new and superior policy instrument being introduced and helping facilitate reform was the US cap and trade policy for sulfur dioxide. Not only did this reduce the cost of reducing emissions relative to the previous regulatory approach of mandatory "scrubbing" of exhaust gases, but it provided opportunities to distribute valuable quotas in ways that helped facilitate acceptance of reforms (Joskow and Schmalensee 2009). Similarly, Levy and van Wijnbergen (1995) showed that the losses to the poor associated with reducing protection to maize in Mexico following NAFTA could be mitigated, or reversed, by increasing investments in irrigation.

Application of new approaches is, however, no guarantee of success. The cap and trade mechanism that worked for reforming US policies on acid rain was not able to generate the needed support for the Kyoto Protocol. The challenges of free-riding, difficulties in communicating the need and potential effectiveness of this approach, and opposition from special interests required a move to more flexible alternatives under the Paris Agreement (UN 2015).

The challenges involved with non-point-source pollution such as GHG from agriculture are even greater than with point-source pollution such as acid-rain from smokestacks because the individual sources of pollution are much harder to monitor and restrain. The non-point-source problem arises at the river-basin level with freshwater quality, where recommended solutions include improving nutrient use efficiency; phasing out fertilizer subsidies, and land management changes such as no-till cropping (IFPRI and Veolia 2015). 
It may also be important to consider complementarity between instruments. If, for instance, governments sought to reduce consumption of emission-intensive commodities such as beef, they would likely want to use multiple instruments, with consumer education and "nudges" alongside complementing mandatory policies such as consumer taxes. As another example, increasing investments in research and development may increase the competitiveness of a country's producers enough to make trade liberalization more readily acceptable.

Many advocates of reform on nutrition or environmental measures frequently claim that trade rules reduce their space for action on these concerns. Some advocate that those interested in nutrition or environmental concerns should invest in learning about WTO rules to find loopholes through which their initial thoughts on policy action can be driven (e.g., Thow et al. 2011). This is, in our view, an ill-advised strategy. As emphasized in Martin (2018b), most environmental and nutritional problems are associated with the level and/or composition of production or consumption, and not the level of trade - except for environmental problems directly associated with trade, such as emissions from use of bunker oil or aviation fuel ${ }^{10}$. WTO rules are, in fact, extremely permissive on policies designed to influence consumption or production — such as taxes on or subsidies to production - as long as these do not discriminate between domestic and foreign goods. Focusing on the source of the externality leads to policies that do not run afoul of WTO rules and allows reformers to focus on good policies to deal with the problems at hand, rather than becoming bogged down in unnecessary conflicts about compliance with trade rules.

\section{Geographic Scope of Negotiations}

Negotiations about policy reform may be conducted at many levels, including:

(i) Sub-national

(ii) National

(iii) Regional, and

(iv) Global

The principle of subsidiarity (Follesdal 1998) provides a useful principle that policy should be made at the lowest appropriate level. When environmental problems, for instance, are local, this

\footnotetext{
${ }^{10}$ These problems can also be addressed under WTO rules through measures such as fuel taxes, as long as the policy measures do not discriminate between internal and external trade.
} 
allows the people best informed about the problem to make the needed decisions on managing it. Another advantage is that it avoids imposing the preferences of people not directly affected by the problem or the policy solution on those who are. Elinor Ostrom won the 2009 Nobel Prize for Economic Sciences ${ }^{11}$ by showing that local communities frequently managed natural resource problems without intervention from higher levels of government or the use of traditional economists' solutions of taxes or assignment of property rights (Ostrom 1990).

Many environmental problems are purely national or sub-national in scope and hence amenable to solution at that level. Policy makers at those levels can use both rewards for compliance and punishments for non-compliance in a way that is generally not feasible in agreements between sovereign governments. Further, policy makers can make tradeoffs across a wide range of issues - a practice sometimes known as log-rolling — in order to secure agreement.

Policies that are attractive at national level and contribute to broader solutions have huge advantages in not requiring a cross-national consensus. However, the global impact of such policies needs to be carefully studied. Many such policies face the problem of spillovers, where reductions in emissions in one country are at least partially compensated for by increases in another (see, e.g., Koesler et al. 2016). A tax on agricultural emissions in one country, for example, reduces output, raises prices and thereby increases output in other countries, where emission intensities may be higher.

National investments in cost-saving technologies encounter a similar problem in that reductions in the cost of the good increases demand via the so-called rebound effect (Binswanger 2001). However, if trade is open, these improvements in productivity lower prices in the rest of the world, and reduce production there, creating a favorable spillover effect on emissions. This spillover effect will be larger again if the new technology can be adopted-whether because it is open-source or via a patent system - and increase productivity in the rest of the world. Since agricultural productivity growth has more powerful poverty-reduction impacts than productivity growth in other sectors - whether it is adopted in one or many countries - this is enormously important for economic development and poverty reduction (Ivanic and Martin 2018). If the improvement in technology is focused on emission reduction the rebound effect will be limited

\footnotetext{
${ }^{11} \mathrm{https}: / /$ www.nobelprize.org/prizes/economic-sciences/2009/ostrom/lecture/
} 
because consumers don't directly gain. If this innovation can also be adopted in the rest of the world, the environmental gain will be larger again. Of course, an integrated and larger international research program would be even better, but how easy would it be to implement?

Problems that are regional, such as acid rain problems in Europe or pollution of rivers that cross national boundaries, are likely to require, or at least to benefit from, coordinated action between governments. Problems such as global warming are also likely to benefit from actions coordinated across countries, unless there are solutions that are either low cost, as appears to have been the case with the Montreal Protocol on substances that deplete the ozone layer ${ }^{12}$, or innovations that producers voluntarily choose to adopt.

Agreements at regional or global level are harder to reach than at national level, and face enforcement challenges more difficult than those at national or sub-national level. Because international institutions tend to focus on vertical silos, such as the WTO for trade policy, the IMF for international macroeconomic coordination, and regional and bilateral fora for military and defense co-ordination, it is also more difficult to make trade-offs across issues.

However, addressing a problem through an international negotiation may have major advantages. One is that it becomes easier to avoid problems of free riding and hence reduces the cost to each country of achieving its goals. It may also change the set of domestic interest groups involved in a question. This is critical in trade policy, where exporters seeking reductions in partner-country tariffs become a counterweight to domestic protectionist lobbies in trade negotiations. A more-subtle advantage is that it can help manage the time inconsistency problems of sovereign governments. Under normal circumstances, a government cannot commit on behalf of its successors and so is unable to reassure investors that its reforms will endure. This can reduce investor confidence and reduce investments that depend on future policies. Committing to keep future tariffs on intermediate goods may be vitally important in attracting export-oriented investors. A trade agreement may allow such a commitment, or at least increase the cost to a future government of reversing such a policy.

\footnotetext{
${ }^{12}$ https://treaties.un.org/Pages/ViewDetails.aspx?src=IND\&mtdsg_no=XXVII-2-a\&chapter=27\&clang=_en
} 


\section{Paths to Reform}

Ideally, reform advocates would begin by identifying their goals, the instruments on which to focus, and the geographic focus of negotiations. It is possible, indeed likely, that some of these features will have been decided by others, and reformers will have opportunities to influence them only at the margin. However, once these features of the policy debate have been chosen, the remaining challenge is to convince the relevant decision makers on the right policy choice.

In an open political system, formulating a policy that is both an improvement in an economic sense and acceptable to policy makers generally requires a combination of analysis and advocacy. Analysis can help organize the information about proposals and answer questions that cannot be answered just from theory or logic, such as: Will this proposal increase national income, and by how much? Will it reduce the number of people in poverty? By how much will it reduce emissions? Analysis is more challenging but potentially more useful with partial reforms. If, for instance, a subsidy on a product that is less subsidized than average is lowered, the theory of the second-best (Lipsey and Lancaster 1956) tells us that this is likely to reduce national income, even though lowering subsidies on all commodities would raise it. Modern quantitative techniques can warn us when these problems are likely to be serious.

Analysis is particularly useful early the policy-making process, when it can help identify the potential economic gains from reform and when - hopefully - policymakers are open to influence because they have not fully committed to specific positions. Other windows of opportunity are likely to arise later in the policy process. Ideally, researchers should interact with key policy makers in advance, to help ensure that their research is addressing the questions of greatest interest to policy makers and to build understanding and foster communication between researchers and policy makers. Mayne et al. (2018) describe OXFAM's process of policy campaigning, as beginning with a foundational report that lays out basic analysis and recommendations. Results from analysis need to be translated into a form that can be understood by policy makers, who may not have formal training in the area. This form is likely to differ between audiences with, for example, policy makers more interested in big ideas and compelling stories, and civil servants in seeking assurance that the work is objective and rigorous (Mayne et al. 2018, Table 2). 
Once the preliminary analysis to guide policy advocacy has been undertaken, reformers can move to the next stage of the process. This is widely seen as assembling Advocacy Coalitions (Weible et al. 2009) or Discourse Coalitions (Hajer 1993), in which an understanding of policy options is forged, topics are framed in specific ways and narratives that can communicate the essence of the problem to a broad audience developed. The establishment of a new coalition can clearly be enough of a shock to a particular policy system to create a change in policy. The formation of the Cairns Group of Agricultural Exporters during the Uruguay Round of trade negotiations is perhaps such a case (Tyers 1993). But, as noted by Weible et al. (2009, p129), the positions of advocacy coalitions tend to be stable over time. This means that, once a set of coalitions has been formed, it may be challenging to secure continuing policy reform.

In this situation, Weible et al. (2009, p124) identify four potential paths to policy change: (i) external shocks to the policy subsystem, (ii) policy-oriented learning, (iii) internal subsystem shocks, such as observed failure of current policies, and (iv) negotiated agreements involving two or more coalitions.

Of these paths to reform, the first has ambiguous effects. Some external shocks, such as the rise in concern about global environmental impacts since the 1990s, might accelerate environmental policy reform, while others such as the current enthusiasm for coal among populist leaders, may hinder it. Waiting for favorable external shocks seems no more a strategy than waiting for something to turn up during hard economic times. However, external shocks, such as crushing overall budget pressures and debt accumulation, can be a powerful stimulus to reform. The New Zealand agricultural reforms of the mid-1980s were one of the most profound examples of this, with subsidy reduction brought about partly because of a serious debt-build up and partly out of a realization that the previous policy of subsidies to expansion of the sheep flock had serious adverse environmental consequences (Vitalis 2007). The structural adjustment programs introduced in much of the developing world in the 1980s and early 1990s in response to acute balance of payments problems frequently removed agricultural subsidies and taxes, but frequently paid insufficient attention to the need for investments in public goods such as research and development (see, e.g., Commander 1988).

Policy-oriented learning, by contrast, has enormous potential for improving policy outcomes - especially if the learning focuses on policies that are attractive to countries 
individually, and so does not require collective action to be effective. If, for instance, ways could be found to modify enteric fermentation in ruminants so that its methane by-product was used productively, the benefits in terms of global emission reduction could be enormous. Large reductions in emissions might also be obtained if non-leguminous plants could be modified to fix their own nitrogen from the air, obviating, or at least reducing, the need for nitrogenous fertilizers (see van Deynze et al. (2018) for some promising recent developments). Learning about demand-oriented approaches that lead to healthy diet choices could allow countries to implement nutrition programs that improve health and the environment (Springmann et al. 2017) without requiring coordination between countries.

Internal subsystem shocks are, like external shocks, ambiguous in their effects. Some shocks may create opportunities for reform, while others may hinder it. The apparent success of cap and trade policies in dealing with acid rain in the US encouraged interest in this policy approach, while its failure under the Kyoto protocol discourages interest in this approach, perhaps even where it might have been successful. Many internal shocks, such as budget constraints making it difficult to continue with subsidy programs, however generate crises that provide important opportunities for reform. Higgs (2011) formalizes the famous policy quip "a crisis is a terrible thing to waste" ${ }^{13}$, pointing out that many government programs, including the seminal US Agricultural Adjustment Act of 1933, involved implementing proposals that had previously been rejected. The importance of crises in policy reform makes it important that the library shelves are stocked with proposals for desirable policy reforms, rather than relying on analysis undertaken on the spot, in the thick of a crisis, or on self-serving analyses generated by special interests. This crisis model of policy influence builds a case for conducting and disseminating analyses of good and important reforms, even when the prospects for immediate implementation of the proposals are not good.

\section{Conclusions}

This paper has shown that agricultural support continues to be an important source of distortions to agricultural incentives in both rich and poor countries. Protection rates have come down considerably in the rich countries, but they continue to be substantial, particularly on rice, milk

\footnotetext{
${ }^{13}$ Rosenthal https://www.nytimes.com/2009/08/02/magazine/02FOB-onlanguage-t.html attributes this quote to Paul Romer in 2004. Similar sayings are frequently attributed to Winston Churchill and Rahm Emmanuel.
} 
and meat products with very high emission intensities. Important progress has been made there, however, in moving away from distorting forms of support to decoupled support in developed countries. In the non-OECD countries, protection rates have gone from negative to positive, on average, although many commodities (especially cash crops) remain subject to taxation, and the average rate of protection has been strongly negative in India.

It is important to consider environmental impacts of agricultural activities and support given to agriculture since agricultural production and land use contribute a disproportionately large share of GHG emissions relative to their share in global GDP. Most emissions of greenhouse gases from agriculture are from rice, milk and livestock commodities, with ruminant meat the most important by far. Emission intensities are substantially higher in the developing countries at this stage, but these intensities have fallen far more rapidly in developing countries than in the rich countries in the past quarter-century, as agricultural productivity has increased in developing countries. However, rich countries and upper-middle income countries consume more dairy and meat products per capita than poorer countries, and these commodities have relatively higher emission intensities.

Our analysis shows that in the early 1990s, agricultural support was lower for emissionintensive goods than for other goods, but now appear to be slightly biased towards emissionintensive goods. Making agricultural subsidies conditional on use of lower-emission approaches is a tempting approach but appears to have had relatively little impact in the past. It seems likely that more comprehensive approaches are likely to be needed if substantial progress is to be made on subsidy reform.

Policy reform is a difficult challenge, especially in aa sector such as agriculture, where special interests are accustomed to having, and exerting, substantial economic power. Some simple models of political economy would suggest that this makes reform impossible. Fortunately, there does still seem to be a role for policy reform if these constraints are recognized. Reformers need to think hard about the goals that they would like to see policies pursue; the policy instruments they seek to change; the geographic scope of negotiations. Once these have been identified then policy advocacy is likely to be needed, taking advantage of opportunities created by internal and external shocks, and making extensive use of analysis designed to identify policy reforms that are both feasible and welfare improving. 


\section{References}

Alston, J. (2018), 'Reflections on agricultural R\&D, Productivity, and the Data Constraint: Unfinished Business, Unsettled Issues' American Journal of Agricultural Economics 100(2): 392-413. doi: 10.1093/ajae/aax094

Anderson, K. (1995). 'Lobbying Incentives and the Pattern of Protection in Rich and Poor Countries.' Economic Development and Cultural Change 43(2): 401-423.

Anderson, K. (2009), Distortions to Agricultural Incentives: A Global Perspective 1955-2007, Palgrave Macmillan and the World Bank, Washington DC.

Babu, S., Gajanan, S. and Hallam, J. A. (2017), Nutrition Economics Principles and Policy Applications, Academic Press, London.

Binswanger, M. (2001), 'Technological progress and sustainable development: what about the rebound effect?' Ecological Economics 36: 119-32.

Birner, R., Gupta, S. and Sharma, N. (2011), The Political Economy of Agricultural Policy Reform in India Fertilizers and Electricity for Irrigation, International Food Policy Research Institute, Washington DC.

Boadi, D., Benchaar, C., Chiquette, J. and Massé, D. (2004), 'Mitigation strategies to reduce enteric methane emissions from dairy cows: Update review' Canadian Journal of Animal Science 84: 319-335.

Byerlee, D. (in press), Globalized agriculture and tropical deforestation. In Gustafson, J., Raven, P. and Erhlich, P. (eds). Population, Agriculture, and Biodiversity. University of Missouri Press, St Louis, MO.

Coase, R. (1960), 'The Problem of Social Cost' Journal of Law and Economics 1:1-44.

Commander, S. (1988), 'Structural Adjustment Policies and Agricultural Growth in Africa' Economic and Political Weekly 23(39): A98-A105.

Condon, N., Klemick, H., and Wolverton, A. (2015), 'Impacts of Ethanol Policy on Corn Prices: A Review and Meta-analysis of Recent Evidence' Food Policy, 51: 63-73.

Engel, S. and Muller, A. (2015), 'Payments for environmental services to promote "climatesmart agriculture’? Potential and challenges' Agricultural Economics 47S: 173-184.

ERS. (2011), 'Measuring the Indirect Land-Use Change Associated with Increased Biofuel production; A Review of Modeling Efforts', Report to Congress, February 2011.

Fan, Shenggen, Cho, E. and Rue, C. (2018) 'Returns to public agricultural and rural investments in China', China Agricultural Economic Review 10(2):215-23, https://doi.org/10.1108/CAER-11-2017-0211

FAO. 1996. 'Rome Declaration on World Food Security and World Food Summit Plan of Action’ World Food Summit 13-17 November 1996. Rome.

FAO (2013), The State of Food and Agriculture: Food Systems for Better Nutrition, FAO, Rome. FAO (2017). The future of food and agriculture - Trends and challenges, FAO, Rome.

FAOSTAT. (2019) Database. Available online at http://www.fao.org/faostat/en/\#home. 
Fargione, J, Hill, J, Tilman, D, Polasky, S, and Hawthorne, P. (2008), 'Land Clearing and the Biofuel Carbon Debt' Science, 319(5867): 1235.

Fukase, E., and Martin, W. (2017), 'Economic Growth, Convergence, and World Food Demand and Supply.' Policy Research Working Paper 8257, World Bank, Washington, DC.

Follesdal, A. (1998), 'Subsidiarity’ Journal of Political Philosophy 6(2): 190-218

Gerber, P., Vellinga, T., Opio, C. and Steinfeld, H. (2011), 'Productivity Gains and Emissions Intensity in Dairy Systems' Livestock Science 139: 100-108.

Gocht, A., Ciaian, P., Bielza, M., Terres, J-M, Röder, N., Himics, M. and Salputra, G. (2017) 'EU-wide Economic and Environmental Impacts of CAP Greening with High Spatial and Farm-type Detail', Journal of Agricultural Economics 68(3) 651-81. doi: 10.1111/14779552.12217

Glauber, J. (2018), Domestic support measures in the context of adaptation and mitigation to climate change Background paper for The State of Agricultural Commodity Markets (SOCO) 2018, FAO, Rome.

Goodwin, B., Mishra, A. and Ortalo-Magné, F. (2012), 'The Buck Stops Where? The Distribution of Agricultural Subsidies' in Zivin, J. and Jeffrey M. Perloff, J. eds. The Intended and Unintended Effects of U.S. Agricultural and Biotechnology Policies, University of Chicago Press for NBER, Chicago.

Hajer, M. (1993), 'Discourse Coalitions and the Institutionalization of Practice: the Case of Acid Rain in Britain' in Fischer, F. and Forester, J. eds. The Argumentative Turn in Policy Analysis and Planning, Duke University Press, Durham and London.

Hardin, R. (1982), Collective Action, Johns Hopkins Press, Baltimore.

Hathaway, D. and Ingco, M. (1995), 'Agricultural liberalization and the Uruguay Round' in Martin, W. and Winters, L.A. eds. (1996), The Uruguay Round and the Developing Countries, Cambridge University Press, Cambridge.

Headey, D. and Fan, S. (2008), 'Anatomy of a crisis: the causes and consequences of surging food prices', Agricultural Economics, 39 375-391

https://onlinelibrary.wiley.com/doi/full/10.1111/j.1574-0862.2008.00345.x

Henderson, B. and J. Lankoski (2019), 'Evaluating the environmental impact of agricultural policies’, OECD Food, Agriculture and Fisheries Papers, No. 130, OECD Publishing, Paris. http://dx.doi.org/10.1787/add0f27c-en

Higgs, R. (2009), 'The Political Economy of Crisis Opportunism’ Policy Primer No 11, Mercatus Center, George Mason University, VA.

Huang, Jikun, Wang, Xiaobing, Zhi, Huayong, Huang, Zhurong and Rozelle, S. (2011), 'Subsidies and Distortions in China's Agriculture: Evidence from Producer-level Data' Australian Journal of Agricultural and Resource Economics 55, pp. 53-71.

IPCC (2006), 2006 IPCC Guidelines for National Greenhouse Gas Inventories, Prepared by the National Greenhouse Gas Inventories Programme, Eggleston H.S., Buendia L., Miwa K., Ngara T. and Tanabe K. (eds). Institute for Global Environmental Strategies, Japan. https://www.ipcc-nggip.iges.or.jp/public/2006gl/vol4.html 
IFPRI and Veolia (2015), 'The murky future of global water quality: New global study projects rapid deterioration in water quality'. http://www.ifpri.org/publication/murky-futureglobal-water-quality-new-global-study-projects-rapid-deterioration-water

Ivanic, M. and Martin, W. (2018), 'Sectoral Productivity Growth and Poverty Reduction: National and Global Impacts' World Development 109: 429-39.

Jayne, T. and Rashid, S. (2013), 'Input subsidy programs in sub-Saharan Africa: a synthesis of recent evidence' Agricultural Economics 44: 547-62.

Jayne, T., Mason, N., Burke, W. and Arigac, J. (2018), 'Review: Taking stock of Africa's second-generation agricultural input subsidy programs' Food Policy 75: 1-14

Johnson, D.G. (1991), World Agriculture in Disarray, $2^{\text {nd }}$ Edition. MacMillan, London.

Joskow, P. and Schmalensee, R. (1998), 'The Political Economy of Market-Based Environmental Policy: The U. S. Acid Rain Program' Journal of Law and Economics, 41(1): 37-83.

Koesler, S., Swales, K. and Turner, K. (2016), 'International Spillover and Rebound Effects from Increased Energy Efficiency in Germany’ Energy Economics 54: 444-52.

Laborde, D. and H. Valin. (2012), 'Modeling Land-use Changes in a global CGE: Assessing the EU Biofuel Mandates with the MIRAGE-BioF Model', Climate Change Economics, 3(3): 1250017.

Laborde, D., Majeed, F.Tokgoz, S. and M. Torero, M. (2016), 'Long-Term Drivers of Food and Nutrition Security' IFPRI Discussion Paper 01531. Washington, D.C..

Levy, S. and van Wijnbergen, S. (1995), 'Transition Problems in Economic Reform: Agriculture in the North American Free Trade Agreement' American Economic Review 85(4): 73854.

Lichtenberg, E. (2018), Conservation Programs in the 2018 Farm Bill, American Enterprise Institute, Washington DC.

Lipsey, R. and Lancaster, K. (1956), 'The General Theory of Second Best' Review of Economic Studies 24(1): 11-32.

Machiavelli, N. (1532), The Prince, Accessed from https://www.planetebook.com/freeebooks/the-prince.pdf on 3 March 2019.

Martin, W. (1990), 'Public Choice Theory and Australian Agricultural Policy Reform' Australian Journal of Agricultural Economics 34(3):189-211.

Martin, W. (2018a), 'Economic Growth, Convergence and Agricultural Economics' Presidential Address to the $30^{\text {th }}$ International Conference of Agricultural Economists, Vancouver, BC, 29 July.

Martin, W. (2018b) 'Food Trade Policy and the Dietary Transition' Policy Brief PB-10/07, OCP Policy Center (Now Policy Center for the New South), Rabat, Morocco. http://www.policycenter.ma/publications/food-trade-policy-and-dietary-transition

Martin, W. and Winters, L.A. eds. (1996), The Uruguay Round and the Developing Countries, Cambridge University Press, Cambridge. 
Masters, W. Hall, A., M. Martinez, E., Shi, Peilin, Singh, G., Webb, P. and Mozaffarian, D. (2015), 'The nutrition transition and agricultural transformation: a Preston curve approach' Agricultural Economics 47 S: 97-114

Mayne, R., Green, D., Guijt, I., Walsh, M., English, R. and Cairney, P. (2018), 'Using evidence to influence policy: Oxfam's experience' Palgrave Communications 4(122):1-10. doi:10.1057/s41599-018-0176-7

Mayrand, K., Dionne, S., Paquin, M., Pageot-LeBel, I. (2003), The Economic \& Environmental Impacts of Agricultural Subsidies: An Assessment of the 2002 US Farm Bill \& Doha Round, Unisféra International Centre, https://unisfera.org/en/publications details.sn?pub=5

Mogues, T., Yu, Bingxin, Fan, Shenggen and McBride, L. (2012), 'The impacts of public investment in and for agriculture: Synthesis of the existing evidence', ESA Working paper No. 12-07, Food and Agriculture Organization, Rome.

OECD (2016), OECD’s Producer Support Estimate and Related Indicators of Agricultural Support, OECD, Paris.

OECD (2018), Agricultural Policy Monitoring and Evaluation 2018, OECD Publishing, Paris. http://dx.doi.org/10.1787/agr pol-2018-en.

Olson, M. (1971) The Logic of Collective Action: Public Goods and the Theory of Groups, Revised ed., Harvard University Press, Cambridge MA.

Ostrom, E. (1990), Governing the Commons: The Evolution of Institutions for Collective Action, Cambridge University Press, New York.

Pigou, A.C. (1932), The Economics of Welfare, Macmillan, London.

Poudel, B.N., Paudel, K. Timilsina, G. and Zilberman, D. (2012), 'Providing Numbers for a Food versus Fuel Debate: An Analysis of a Future Biofuel Production Scenario', Applied Economic Perspectives and Policy, 34(4): 637-668.

Schmalensee, R., Joskow, P., Ellerman, A.D., Montero, J.P. and Bailey, E. (1998), 'An Interim Evaluation of Sulfur Dioxide Emissions Trading' Journal of Economic Perspectives 12(3):53-68.

Searchinger, T., Heimlich, R. Houghton, R., Dong, Fengxia, Elobeid, A., Fabiosa, J., Tokgoz, S. Hayes, D., Yu, Tun-Hsiang (2008). 'Use of U.S. Croplands for Biofuels Increases Greenhouse Gases Through Emissions from Land-Use Change' Science 319 (5867):1238-40.

Sen, A. (1981), Poverty and Famines: An Essay on Entitlements and Deprivation. Clarendon Press, Oxford.

Serra, T. and Zilberman, D. (2013), 'Biofuel-related Price Transmission Literature: A Review' Energy Economics, 37: 141-51.

Springmann, M., Mason-D’Croz, D. Robinson, S., Wiebe, K., Godfray, C., Rayner, M. and Scarborough, P. (2017), 'Mitigation potential and global health impacts from emissions pricing of food commodities' Nature Climate Change 7:69-74, January. 
Thow, A., Heywood, P., Schultz, J. Quested, C., Jan, S and Colagiuri, S. (2011) 'Trade and the Nutrition Transition: Strengthening Policy for Health in the Pacific' Ecology of Food and Nutrition' 50(1): 18-42, DOI: 10.1080/03670244.2010.524104

Tilman, D. and Clark, M. (2014) 'Global Diets Link Environmental Sustainability and Human Health' Nature 515: 518-24.

Tinbergen, J. (1956), Economic Policy: Principles and Design, North Holland, Amsterdam.

Tokgoz, S., D. Torres, A. Laborde, D. and Huang, J.(2014), 'The Role of U.S., China, Brazil's Agricultural and Trade Policies on Global Food Supply and Demand' FOODSECURE Working Paper No. 19, Wageningen University and Research Centre, http://www3.lei.wur.nl/FoodSecurePublications/19_Tokgoz_et-al_US-China-Brasiltrade-policies.pdf

Tubiello, F., (2019), 'Greenhouse Gas Emissions Due to Agriculture', in Ferranti, P., Berry, E.M. and Anderson, J.R. (eds.), Encyclopedia of Food Security and Sustainability, vol. 1, Elsevier, Amsterdam, 196-205.

Tubiello, F., Salvatore, M., Rossi, S., Ferrara, A., Fitton, N. and Smith, P. (2013), 'The FAOSTAT database of greenhouse gas emissions from agriculture' Environmental Research Letters 8015009 (10pp) doi:10.1088/1748-9326/8/1/015009

Tubiello, F., Salvatore, M., Rossi, S. and Ferrara, A. (2012) 'Analysis of global emissions, carbon intensity and efficiency of food production' Energia, Ambiente e Innovazione 8793. http://www.enea.it/it/seguici/pubblicazioni/pdf-eai/luglio-ottobre-2012/primaparte/studi-research-analysis-emissions-food-production-

Tyers, R. (1993), 'The Cairns Group and the Uruguay Round of International Trade Negotiations' Australian Economic Review 26(1):49-60. doi.org/10.1111/j.14678462.1993.tb00771.x

UN (2015), Paris Agreement, United Nations, New York https://reaties.un.org/doc/Treaties/2016/02/20160215\%2006-03\%20PM/Ch_XXVII-7d.pdf

Van Deynze A, Zamora P, Delaux P-M, Heitmann C, Jayaraman D, Rajasekar S, et al. (2018) Nitrogen fixation in a landrace of maize is supported by a mucilage-associated diazotrophic microbiota. PLoS Biol 16(8): 1-21. e2006352. https://doi. org/10.1371/journal.pbio.2006352

Vitalis, V. (2007), 'Agricultural subsidy reform and its implications for sustainable development: the New Zealand experience', Environmental Sciences 4(1):21-40, DOI: $10.1080 / 15693430601108086$

Weible, C., Paul A. Sabatier, P. and McQueen. K. (2009), 'Themes and Variations: Taking Stock of the Advocacy Coalition Framework' Policy Studies Journal 37(1):121-40. 
Willett, W., Rockström, J., Loken, B., Springmann, M., Lang, T., Vermeulen, S., Garnett, T., Tilman, D., DeClerck, F., Wood, A., Jonell, M., Clark, M., Gordon, L., Fanzo, J., Hawkes, C., Zurayk, R., Rivera, J., De Vries, W., Majele Sibanda, L., Afshin, A., Chaudhary, A., Herrero, M., Agustina, R., Branca, F., Lartey, A., Fan, Shenggen, Crona, B., Fox, E., Bignet, V., Troell, M., Lindahl, T., Singh, S., Cornell, S., Reddy, K. S., Narain, S., Nishtar, S. Murray, C. (2019), 'Food in the Anthropocene: the EAT-Lancet Commission on healthy diets from sustainable food systems' Lancet 2019; 393: 447-92. http://dx.doi.org/10.1016/S0140-6736(18)31788-4

WTO (2019), 'China - Domestic Support for Agricultural Producers: Report of the Panel, World Trade Organization, Geneva WT/DS511/R

Zhang, W., Yu, E., Rozelle, S., Yang, J. and Msangi, S. (2013), 'The Impact of Biofuel Growth on Agriculture: Why is the Range of Estimates so Wide?' Food Policy 38: 227-239. 


\section{Appendix}

Developments in Agricultural Incentives for Key Countries

While the major impacts on global production, emissions and prices are largely determined by developments in the largest economies, developments in other countries provide important insights into the behavior of policy makers, and the possibilities for reform. Much more detail on policies in these countries is given in the OECD's Monitoring and Outlook reports (OECD 2018). However, in the following graphs, for example, the Australian experience points to the possibility of a sharp movement to decoupled support.

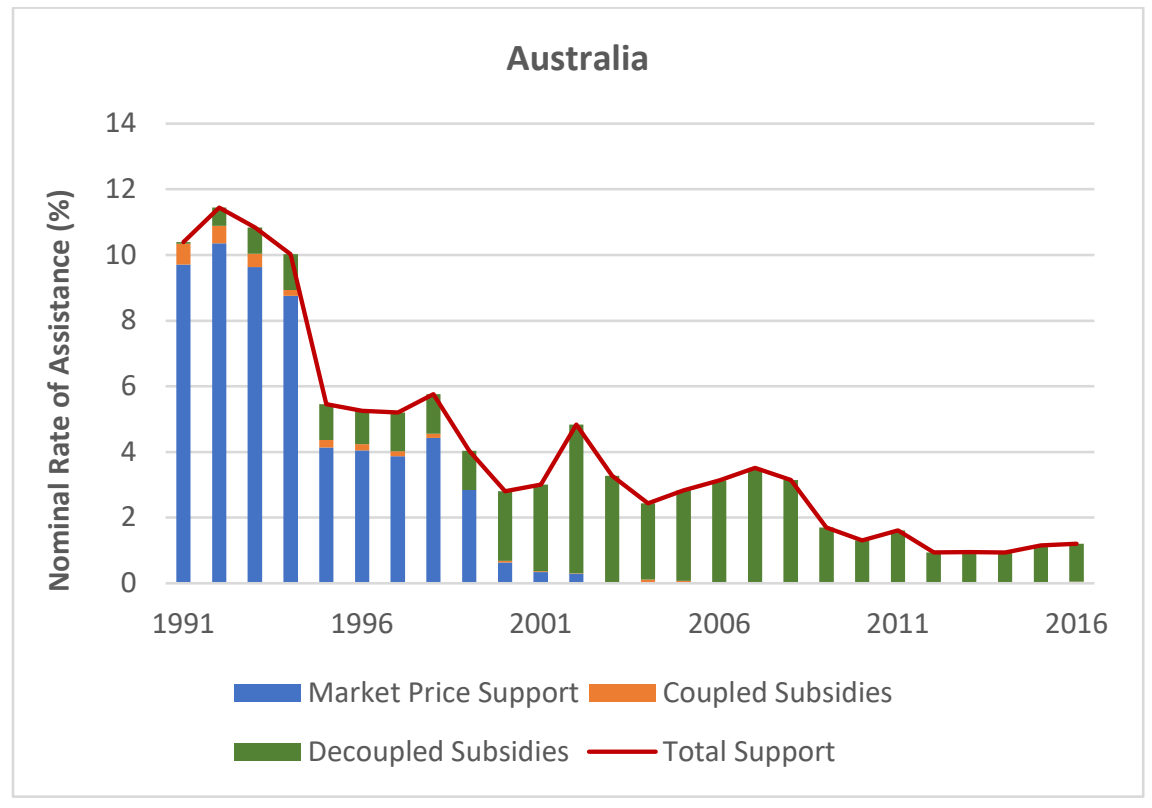


The experience of Colombia, by contrast, shows the relative stability of incentive patterns in many countries.

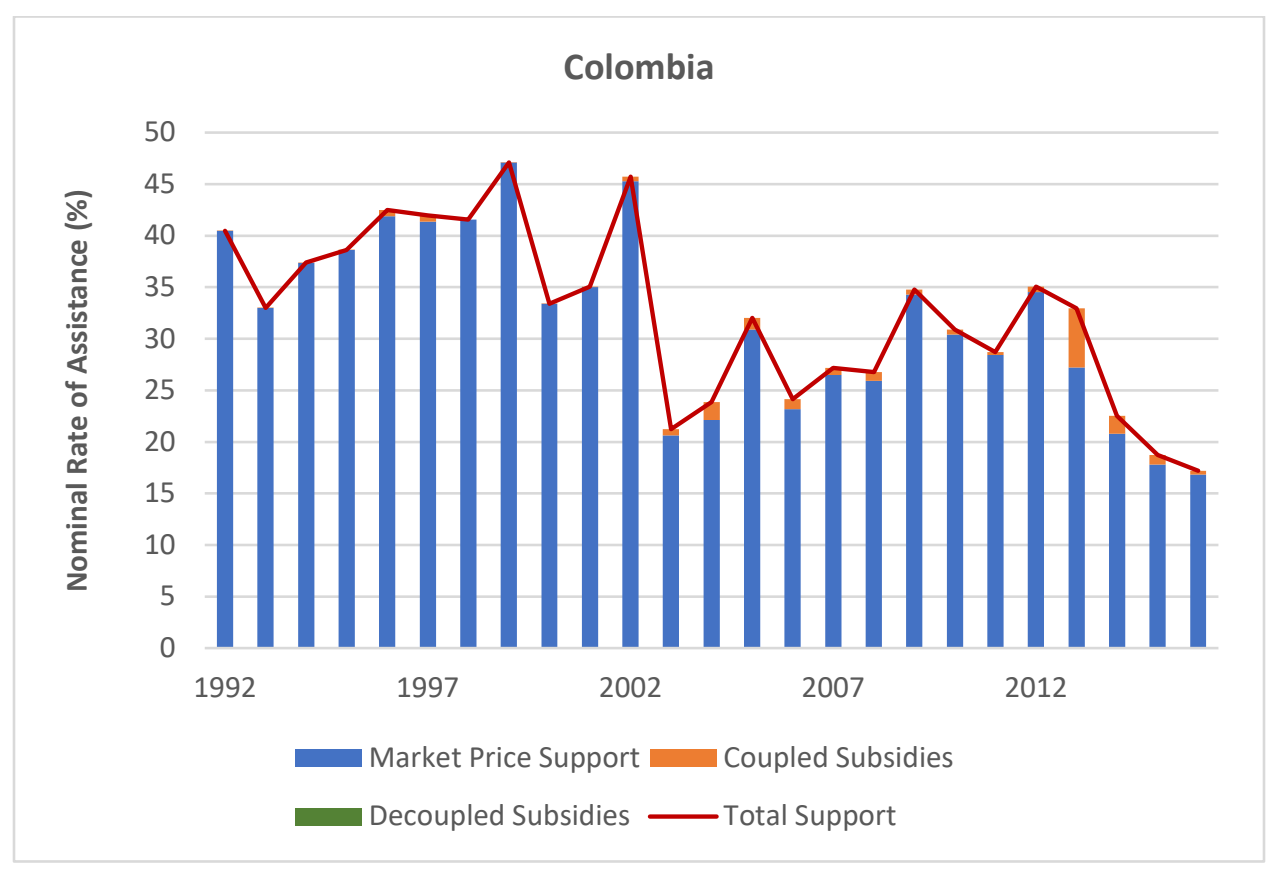

The example of Ethiopia highlights the perseverance of negative protection to agriculture in a large low-income country. This graph also highlights a pattern of protection frequently observed in African countries. Instead of protection moving inversely with world prices in order to stabilize domestic prices, protection increased in the high-priced 2008 year, exacerbating the price increase associated with the food price crisis in that year. 


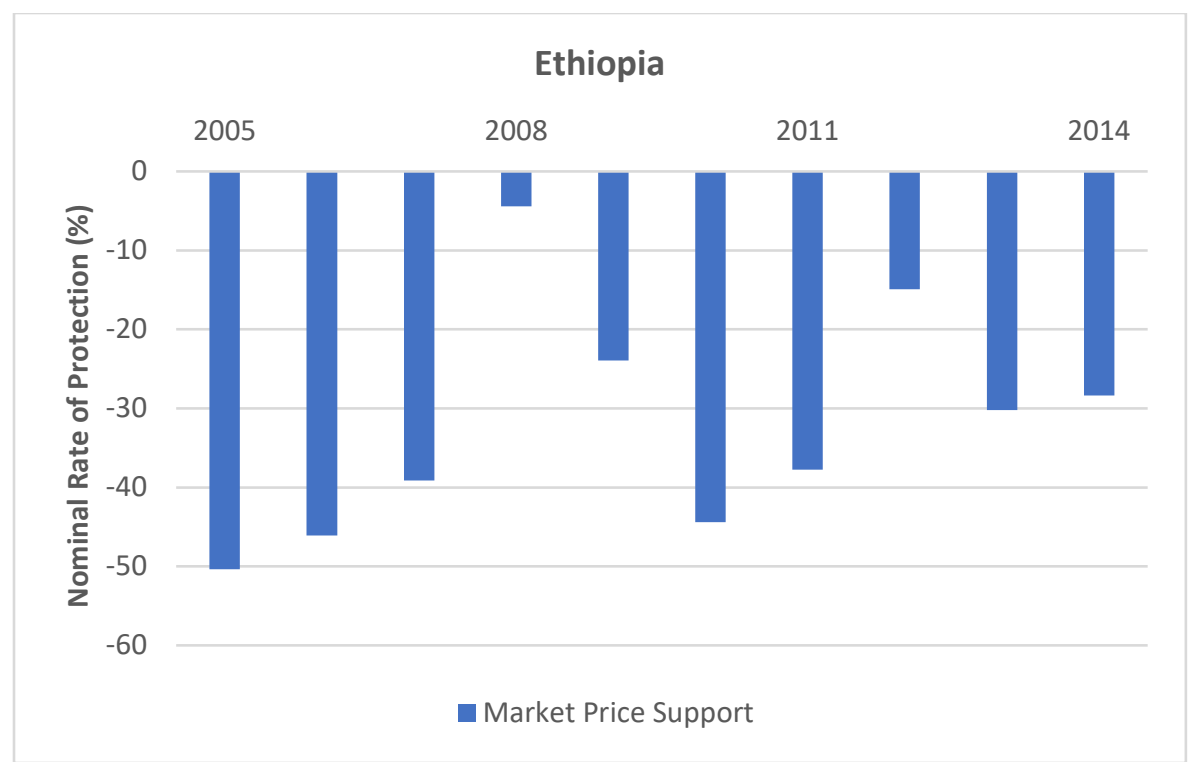

Source: Ag Incentives Consortium, www.ag-incentives.org.

The Indonesia example shows an upward trend from from initially very low protection to quite substantial average rates of protection by the end of the sample period. It also shows countercyclical use of protection policy to stabilize domestic prices, with protection falling in 2008-09 to very low levels - with import subsidies for rice required in 2008.

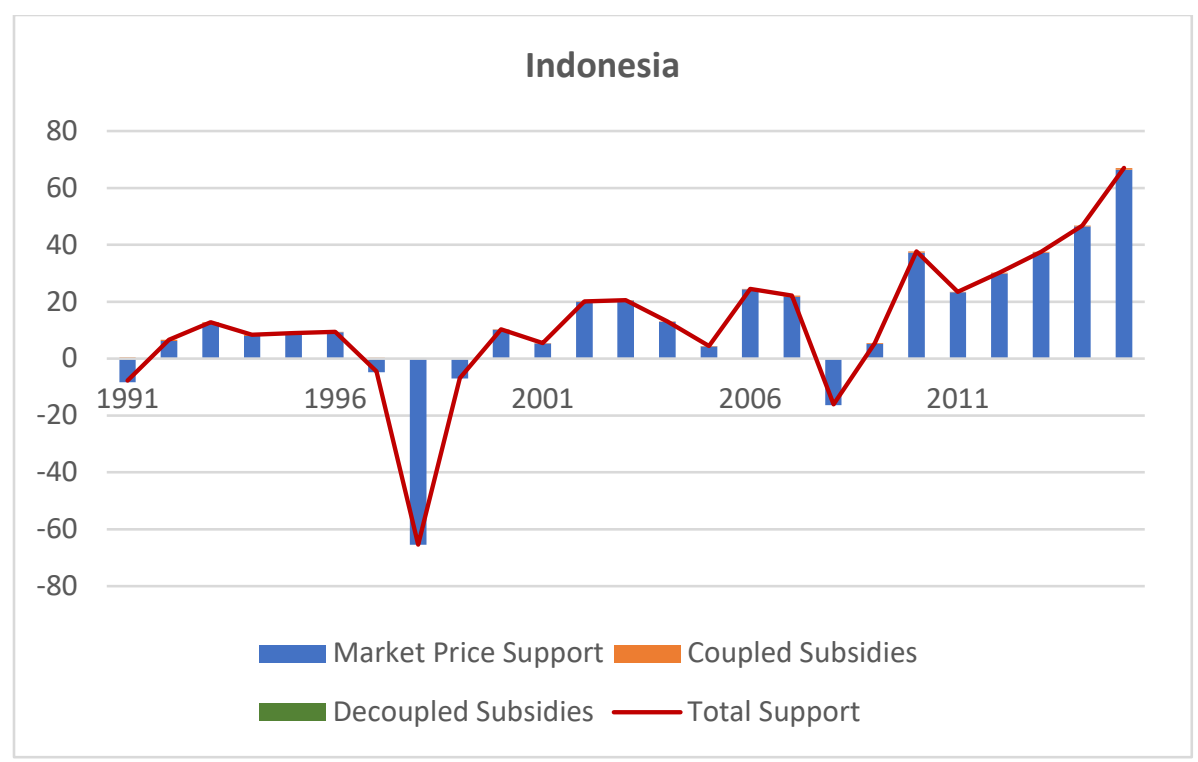




\section{ALL IFPRI DISCUSSION PAPERS}

All discussion papers are available here

They can be downloaded free of charge

INTERNATIONAL FOOD POLICY RESEARCH INSTITUTE

www.ifpri.org

\section{IFPRI HEADQUARTERS}

1201 Eye Street, NW

Washington, DC 20005 USA

Tel.: +1-202-862-5600

Fax: +1-202-862-5606

Email: ifpri@cgiar.org 